\title{
Hydrothermal pretreatment of biomass samples for producing energy efficient hydrogen electrochemically
}

\author{
Laila P. Akkineni \\ West Virginia University
}

Follow this and additional works at: https://researchrepository.wvu.edu/etd

\section{Recommended Citation}

Akkineni, Laila P., "Hydrothermal pretreatment of biomass samples for producing energy efficient hydrogen electrochemically" (2011). Graduate Theses, Dissertations, and Problem Reports. 3301. https://researchrepository.wvu.edu/etd/3301

This Thesis is protected by copyright and/or related rights. It has been brought to you by the The Research Repository @ WVU with permission from the rights-holder(s). You are free to use this Thesis in any way that is permitted by the copyright and related rights legislation that applies to your use. For other uses you must obtain permission from the rights-holder(s) directly, unless additional rights are indicated by a Creative Commons license in the record and/ or on the work itself. This Thesis has been accepted for inclusion in WVU Graduate Theses, Dissertations, and Problem Reports collection by an authorized administrator of The Research Repository @ WVU. For more information, please contact researchrepository@mail.wvu.edu. 
HYDROTHERMAL PRETREATMENT OF BIOMASS SAMPLES FOR PRODUCING ENERGY EFFICIENT HYDROGEN ELECTROCHEMICALLY

\author{
Laila P. Akkineni
}

\begin{abstract}
Thesis submitted to the College of Engineering and Mineral Resources

at West Virginia University in partial fulfillment of the requirements

for the degree of
\end{abstract}

Master of Science

in

Electrical Engineering

Dimitris Korakakis, Ph.D., Chair

Mohindar S. Seehra, Ph.D.,

Larry Hornak, Ph.D.

Lane Department of Computer Science and Electrical Engineering

Morgantown, West Virginia

2011

Keywords: Cellulose, Hydrothermal pretreatment, Electrolysis, Hydrogen production. 


\title{
ABSTRACT \\ HYDROTHERMAL PRETREATMENT OF BIOMASS SAMPLES FOR PRODUCING ENERGY EFFICIENT HYDROGEN ELECTROCHEMICALLY
}

\begin{abstract}
Laila P. Akkineni
In this thesis, electrochemical production of hydrogen $\left(\mathrm{H}_{2}\right)$ gas using two biomass materials, namely microcrystalline cellulose and wood sawdust, has been investigated. Since as obtained samples did not show meaningful activity in hydrogen production, these samples were subjected to hydrothermal pretreatment (HTP) in an autoclave using water as solvent at $200^{\circ} \mathrm{C}$ and up to 500 psi pressure. The HTP samples produced activity as high as that of high surface area activated carbon (BP2000) for producing $\mathrm{H}_{2}$ at energy efficient voltages.

To understand the changes produced by HTP, structural properties of the parent as well as the HTP samples were determined using x-ray diffraction (XRD), scanning electron microscopy (SEM), and Thermo-gravimetric analysis (TGA). From the $\mathrm{x}$-ray diffraction patterns of the parent and the HTP crystalline cellulose and wood sawdust, the parent samples show the crystalline peaks of cellulose whereas all these Bragg peaks were missing in the HTP samples. Instead only a broad peak is observed suggesting loss of crystallinity in the HTP samples. Results from SEM micrograph of the micro-crystalline cellulose show that the particle size of the parent cellulose are about $12 \times 6 \mu \mathrm{m}$ but after HTP, the particle size is reduced by a factor of 50 to yield particles about $210 \mathrm{~nm}$. This reduction in size accompanied by complete less of cellulose crystallinity is the likely reason for the observed high activity of the HTP cellulose to produce $\mathrm{H}_{2}$ electrochemically.
\end{abstract}




\section{Dedication,}

\section{To my Parents,}

I would like to express my hearty thanks to my parents Mr.\& Mrs. AKKINENI JANARDHAN RAO. It is because of their constant support and encouragement I'm what I am today. They gave me the maximum freedom any parents would give. I thank them for believing in me and would take this opportunity to assure them that I will make them proud for what they have given me in life. I also thank my brother PHANINDRA AKKINENI for always being by my side during my difficult times, giving me guidance and to take many crucial decisions in life. 


\section{ACKNOWLEDGEMENTS}

I convey my utmost gratitude and highest respects to Hon'ble Dr. Mohindar Seehra, He is my mentor who has taught me how to learn patiently and do research and also giving me the room to work in my own way. I attribute my success in my Masters degree to his encouragement and effort and without him this thesis, too, would not have been completed or written. One simply could not wish for a better or friendlier advisor.

I am also extremely thankful to my committee members Dr. Dimitris Korakakis and Dr. Lawrence A. Hornak for their valuable suggestions in my research and academics. I express my gratitude to all my colleagues Mohita, Savan, James and Dr. Vivek Singh for their constant support and valuable inputs. I am also very thankful to the professors who have taught me courses in the Electrical Engineering and Physics Departments. I also thank office staff members of the Physics Department viz. Sherry, Phil, Doug and Devon for their helping hands. Finally I thank the U.S. Department of Energy (DE-FC26-05NT42456) for financially supporting this project. 


\section{TABLE OF CONTENTS}

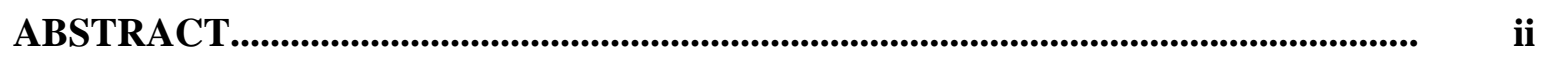

DEDICATION........................................................................................................ iii

ACKNOWLEDGEMENT ............................................................................................ iv

TABLE OF CONTENTS........................................................................................................ v

LIST OF FIGURES............................................................................................... viii

LIST OF TABLES................................................................................................... ix

CHAPTER 1. BACKGROUND AND OBJECTIVES...................................................... 1

1.1 DIFFERENT PROCESSES FOR PRODUCING HYDROGEN... 1

1.2 CARBON-ASSISTED WATER ELECTROLYSIS.................... 3

1.3 OBJECTIVES OF RESEARCH.................................... 4

CHAPTER 2. ENERGY CONSIDERATIONS............................................................... 5

2.1 WATER ELECTROLYSIS........................................ 5

2.1.1 Energy Requirements....................................... 5

2.2 ELECTRO CHEMICAL GASIFICATION OF CARBON.......... 6

2.2.1 Energy Requirements....................................... 7

2.3 RESULTS.......................................................... 8

2.4 PARAMETERS OF INTEREST ................................... 9

CHAPTER 3. EXPERIMENTAL PROCEDURES......................................................... 12

3.1 SYNOPSIS................................................................................................... 12

3.2 SAMPLE PREPARATION ........................................ 12

3.3 EXPERIMENTAL SETUP FOR ELECTROCHEMICAL

EXPERIMENTS............................................................................................ 14 
3.4 GAS CHROMATOGRAPH..................................

3.5 EXPERIMENTAL PROCEDURES........................... 17

CHAPTER 4. RESULTS AND DISCUSSION...................................... 19

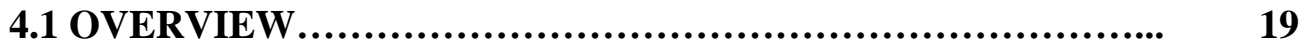

4.2 HYDROTHERMAL PRETREATMENT (HTP).................... 19

4.3 X-RAY DIFFRACTION STUDIES................................. 21

4.4 SEM ANALYSIS................................................ 23

4.5 THERMO-GRAVIMETRIC ANALYSIS (TGA).................. 24

4.6 ELECTRO CHEMICAL PRODUCTION OF HYDROGEN......... 27

4.6.1 Time dependence with HTP cellulose at $250^{\circ} \mathrm{C} \ldots \ldots \ldots \ldots .28$

4.6.2 Results obtained with untreated and HTP- $250^{\circ} \mathrm{C}$ biomass samples.............................................. $\quad \mathbf{2 8}$

4.6.3 Results of HTP cellulose at $200 \mathrm{C}$ and Carbon BP2000...... 30

4.6.4 Results of HTP cellulose for 1 hour at $200 \mathrm{C}$ vs. $250 \mathrm{C} \ldots \ldots \mathbf{3 1}$

4.6.5 Efficiency of energy requirement...................... 32

CHAPTER 5. SUMMARY AND CONCLUSIONS................................... 36

REFERENCES................................................................ 37 


\section{LIST OF FIGURES}

Fig. 2.1: Block diagram of the electrochemical cell used in the experiments................ 9

Fig. 2.2: Plot showing comparison of hydrogen production between WE and CAWE........................................................................................................ 7

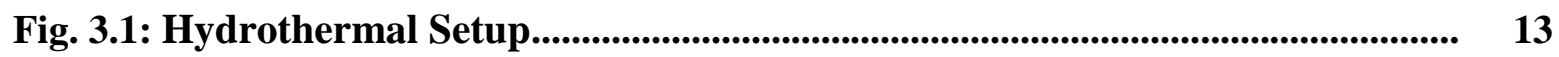

Fig. 3.2: Comparison of sample before and after HTP............................. 13

Fig. 3.3: Photograph and schematic diagram of three-electrode cell used in electrochemical

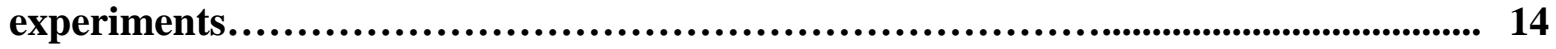

Fig.3.4: Electrochemical setup along with potentiostat used in the experiments............................................................................... 15

Fig. 3.5: Gas Chromatograph Model 8610C............................................................................ 16

Fig.4.1: Plots of changes in pressure and temperature vs. time during HTP.

Fig. 4.2: Comparison of XRD patterns of HTP produced biomass with the parent biomass samples

Fig. 4.3: Comparison of XRD patterns of HTP samples at $15 \mathrm{~min}, 30 \mathrm{~min}$ and 1 hour at 200 C with HTP sample at 1 hour-250 C..

Fig. 4.4(a): SEM micrographs of untreated cellulose (Average particle size $=11,824 \mathrm{x}$ 6,309).

Fig. 4.4(b): SEM micrographs of HP treated cellulose; (Average particle size $=208 \times 208$ nm).

Fig. 4.5(a): SEM micrographs of HP treated sawdust Particle size $=10,186 \times 3,051 \mathrm{~nm} . \ldots . .23$

Fig. 4.5(b): Enlarged SEM view of HP treated sawdust Particle size $=249$ x 248 nm....... 23

Fig. 4.6: Picture of the Thermal Gravimetric Analysis system $\ldots \ldots \ldots \ldots \ldots \ldots \ldots \ldots \ldots .25$

Fig. 4.7: TGA measurements on coal biomass samples treated at $250^{\circ} \mathrm{C} \ldots \ldots \ldots \ldots \ldots . . . .26$ 
Fig. 4.8: TGA behavior of the biomass samples at $200^{\circ} \mathrm{C} \ldots \ldots \ldots \ldots \ldots \ldots \ldots \ldots \ldots \ldots . . . . . .27$

Fig. 4.9: Time dependence plot of the current for HTP cellulose treated at $250^{\circ} \mathrm{C} \ldots . .28$

Fig. 4.10: Comparison of untreated biomass materials (at $250 \mathrm{C}$ ) and WE ......... 29

Fig. 4.11: Plots of HTP biomass sample and carbon BP2000.................... 30

Fig. 4.12: Comparison of HTP biomass materials (at 200 C), carbon BP2000 and WE.31

Fig. 4.13: Comparison between HTP cellulose for 1 hour at $200 \mathrm{C}$ vs. $250 \mathrm{C}$............ 32

Fig. 4.14: Comparison of efficiencies of HTP biomass samples vs. water electrolysis... 33

Fig. 4.15: Comparison of efficiencies of HTP biomass samples vs. water electrolysis... 34 


\section{LIST OF TABLES}

TABLE 1. Comparison of the efficiencies of the various hydrogen production processes 


\section{CHAPTER 1}

\section{Background and Objectives}

Many conflicts in our modern times are caused by the increased energy needs in the world. Steadily oil, coal and natural gas supplies on this planet are diminishing, and the consumption of these limited resources is increasing at an alarming rate, particularly in developing countries. Hence there is a need for conversion from a petroleum based economy to other sources of energy such as hydrogen. Hydrogen is a clean energy carrier made from renewable energy sources like solar energy, fossil fuel, biomass materials etc. Burning fossil fuels such as coal and oil releases $\mathrm{CO}_{2}$, which is now believed to be a major cause of global warming With only $4.5 \%$ of the world's population, United States is responsible for about $25 \%$ of global energy consumption and $25 \%$ of global $\mathrm{CO}_{2}$ emissions. The average price of gasoline in 2005 was $\$ 2.56$ per gallon, which was $\$ 0.67$ higher than the average price of gasoline in the previous year. Yet, in June 2008, the average price of gasoline in the United States reached $\$ 4.10$ per gallon [1].

\subsection{Different Processes for Producing Hydrogen:}

Hydrogen is used as a fuel, and as a feed for producing other fuels and commodities. In future, the role of hydrogen may become more important, as some researchers suggest that the world's energy systems may undergo a transition to an era in which the main energy carriers are hydrogen and electricity. In Table 1, an economic analysis by Rosen and Scott [2] gives comparison of various hydrogen production processes based on their category and their efficiencies.

The hydrogen production processes considered here (see Table I below) based on current technologies includes:

(i) Current and advanced technologies for water electrolysis; and

(ii) Integrated processes that use by-product oxygen from water electrolysis or thermo chemical water decomposition to enhance combustion in the SMR furnace. 


\begin{tabular}{|l|l|l|}
\hline CATEGORY & \multicolumn{1}{|c|}{ PROCESS } & EFFICIENCY(\%) \\
\hline Hydrocarbon based & Steam-methane reforming (SMR) & 86 \\
& Coal gasification & 59 \\
\hline Non-hydrocarbon based & Current- technolgy water electrolysis & 30 \\
& Advanced-technolgy water electrolysis & 49 \\
& Thermochemical water decomposition & 21 \\
\hline Integrated & SMR/Current-technolgy water electrolysis & 55 \\
& SMR/Advanced-technolgy water electrolysis & 70 \\
& SMR/ Thermochemical water decomposition & 45 \\
\hline
\end{tabular}

Table 1. Comparison of the efficiencies of the various hydrogen production processes[2].

From the above table 1, the efficiencies for the processes involving hydrogen production from hydrocarbons (SMR and coal gasification) are relatively high, varying approximately from $59 \%$ for coal gasification to $86 \%$ for SMR. Since the hydrogen-to-carbon atomic ratios for methane (4) and coal (0.8) bracket the range covered by most of the hydrocarbons used in hydrogen production, the efficiencies for hydrogen production from hydrocarbons having intermediate ratios can be expected to lie between those determined here for SMR and coal gasification. On the other hand the efficiencies for the processes involving hydrogen production from non-hydrocarbons (current- and advanced-technology water electrolysis and thermo chemical water decomposition) range from $21 \%$ for thermo chemical water decomposition to almost $50 \%$ for water electrolysis.

Electrolysis of water produces pure hydrogen well separated from pure oxygen. However its efficiency is about a factor of two lower than that of coal gasification (CG) and SMR. The increased costs associated with water electrolysis are primarily due to the cost of electricity used in electrolysis. Thus if water electrolysis is to complete successfully with the CG and SMR processes to produce hydrogen, the amount of hydrogen produced per kilowatt hour of the energy used in water electrolysis has to nearly double. 


\subsection{Carbon-assisted water electrolysis (CAWE):}

About three decades ago, Coughlin and Farooque [3] proposed and tested electrochemical gasification of carbons to produce pure $\mathrm{H}_{2}$ near ambient conditions. The basic reactions of this electrochemical process were proposed to be:

Anode: $\mathrm{C}(s)+2 \mathrm{H}_{2} \mathrm{O}(l) \rightarrow \mathrm{CO}_{2}(g)+4 \mathrm{H}^{+}+4 \mathrm{e}^{-}$

Cathode: $4 \mathrm{H}^{+}+4 \mathrm{e}^{-} \rightarrow 2 \mathrm{H}_{2}(g)$

Net reaction: $\mathrm{C}(s)+2 \mathrm{H}_{2} \mathrm{O}(l) \rightarrow \mathrm{CO}_{2}(g)+2 \mathrm{H}_{2}(g)$

These reactions are to be compared with those for water electrolysis (WE) without carbon:

Net reaction: $2 \mathrm{H}_{2} \mathrm{O} \rightarrow 2 \mathrm{H}_{2}+\mathrm{O}_{2}$

A comparison of the above two processes shows that these reactions differ only in that carbon is oxidized by the liberated oxygen at the anode to produce $\mathrm{CO}_{2}$ in electrochemical gasification or carbon-assisted water electrolysis (CAWE). However, the primary advantage of CAWE is in energy requirements. Theoretically, water electrolysis (WE) requires a minimum energy consumption of $56.7 \mathrm{kcal} / \mathrm{mol} \mathrm{H}_{2} \mathrm{O}$, whereas CAWE requires only $9.6 \mathrm{kcal} / \mathrm{mol} \mathrm{H}_{2} \mathrm{O}$, a factor of about 6 lower in energy. In terms of electrical energy voltage, $\mathrm{E}^{0}>1.23 \mathrm{~V}$ is needed to split $\mathrm{H}_{2} \mathrm{O}$ in WE whereas $\mathrm{E}^{0}>0.21 \mathrm{~V}$ is needed in CAWE [3]. However, to satisfy both the free energy and thermal requirements, $\mathrm{E}^{0} \sim 0.45 \mathrm{~V}$ is the threshold voltage for $\mathrm{Eq}(1.3)$ and $\mathrm{E}^{0} \sim 2.0 \mathrm{~V}$ is the threshold for $\mathrm{Eq}(1.4)$. In the experiments of Coughlin and Farooque [3], $\mathrm{H}_{2}$ production could be observed at $\mathrm{E}^{0} \sim 0.8-1.0 \mathrm{~V}$ with the use of coals as carbon.

A few years back, research into the CAWE process was restarted in our laboratory primarily using activated carbons as the source of carbon. Using carbon GX203 (prepared from coconut shells) with surface area $\sim 1000 \mathrm{~m}^{2} / \mathrm{g}$, Ranganathan et al [4,5] showed hydrogen production beginning at $\mathrm{E}^{0} \sim 0.54 \mathrm{~V}$, very close to the threshold value of $\mathrm{E}^{0} \sim 0.45 \mathrm{~V}$. However at these voltages, the hydrogen production rate $R_{H}$ was quite low and impractical. Follow up experiments by Bollineni et al [6,7] in this laboratory using a variety of additional carbons including graphite, nanotubes and commercial carbon BP2000 (surface area $=1500 \mathrm{~m}^{2} / \mathrm{g}$ ) showed that carbon BP2000 is the most efficient of all the carbons for producing excellent hydrogen 
rates at a very practical and low voltage $\mathrm{E}^{0} \sim 0.9 \mathrm{~V}$ compared to $\mathrm{E}^{0}>2 \mathrm{~V}$ needed for ordinary water electrolysis. Thus a factor of two increase in the needed energy efficiency was shown to be easily achievable using carbon BP2000.

Although hydrogen produced at the cathode in the CAWE process is well separated from the $\mathrm{CO}_{2}$ produced at the anode, the co-production of green-house gas $\mathrm{CO}_{2}$ is still a problem especially using a carbon source. Later experiments by Seehra et al [8] using no carbon but $\mathrm{FeSO}_{4}$ as a catalyst provided essentially similar efficiency; In this case, additional electrons were provided by the redox reaction

$$
\mathrm{Fe}^{2} \rightarrow \mathrm{Fe}^{3+}+\mathrm{e}^{-} \text {at } \mathrm{E}^{0} \sim 0.8 \mathrm{~V} \quad \mathrm{Eq}(1.5)
$$

\subsection{Objectives of Research:}

Biomass energy derived from plant matter is one of many alternative fuel sources being looked at to replace the fossil fuels that we rely so heavily for energy. One of the things that makes biomass so appealing is that it is a renewable resource and it is also in abundance, while fossil fuels exist in finite amounts. Conversion of this abundant lignocellulosic biomass to biofuels as transportation fuels presents a viable option for improving energy security and reducing greenhouse emissions as that from fossil fuels.

In this work, the biomass samples investigated include a sample of microcrystalline

cellulose purchased from Alfa-Aesar and wood sawdust sample collected from our wood machine shop and these samples are treated hydrothermally. After testing on these samples, here we report that significant current and $\mathrm{H}_{2}$ production gets initiated at applied voltages as low as $\mathrm{E}^{\mathrm{O}} \approx 0.5 \mathrm{~V}$. Furthermore, hydrogen evolution rate seems practically identical for the HTP cellulose and activated carbon BP2000, the most efficient carbon tested in previously done experiments making this process of producing hydrogen a possible practical reality. Details of these experimental results and their discussion are presented in the following chapters. 


\section{CHAPTER 2.}

\section{ENERGY CONSIDERATIONS}

\subsection{Water Electrolysis:}

The electrolysis of water is a well-known process to produce oxygen and hydrogen gas from water. In simple terms the electrochemical cell is filled with water and an electrolyte $\left(\mathrm{H}_{2} \mathrm{SO}_{4}\right.$ or $\left.\mathrm{KOH}\right)$ and has two electrodes which are connected with an external power supply. At a certain critical voltage between both electrodes, the electrodes start to produce hydrogen gas at the negatively biased electrode and oxygen gas at the other one. The amount of gas evolved per unit time is directly related to the current passing through the cell.

The basic reactions of water electrolysis are:

Anode: $\quad \mathrm{H}_{2} \mathrm{O} \rightarrow 1 / 2 \mathrm{O}_{2}+2 \mathrm{H}^{+}+2 \mathrm{e}^{-}$.

Cathode: $\quad 2 \mathrm{H}^{+}+2 \mathrm{e}^{-} \rightarrow \mathrm{H}_{2}$.

Net Reaction: $\mathrm{H}_{2} \mathrm{O} \rightarrow \mathrm{H}_{2}+1 / 2 \mathrm{O}_{2}$.

\subsubsection{Energy Requirements:}

From the laws of thermodynamics, the enthalpy of formation for liquid water, $\mathrm{H}_{2} \mathrm{O}(\mathrm{l})$, is $-68.31 \mathrm{kcal} / \mathrm{mol}$ and that of water vapor is $-57.8 \mathrm{kcal} / \mathrm{mol}$. The difference is the heat of vaporization at $298 \mathrm{~K}$ (i.e. @ 25 $\mathrm{C}$ ). Liquid water and vapor entropies $(S)$ are 16.71 and $45.132 \mathrm{kcal} \mathrm{K}^{-1} \mathrm{~mol}^{-1}$ respectively; these are entropies, but not standard entropies of formation Considering the net reaction,

$$
\mathrm{H}_{2} \mathrm{O} \rightarrow \mathrm{H}_{2}+1 / 2 \mathrm{O}_{2}
$$

The entropy of formation for water is obtained by,

$$
\begin{aligned}
& \Delta S_{\text {f water }}^{\mathrm{o}}=S_{\text {water }}^{\mathrm{o}}-S_{\mathrm{H} 2}^{\mathrm{o}}-0.5 S_{\mathrm{O} 2}^{\mathrm{o}} \\
& \quad=16.70-31.23-0.5^{* 49} .03 \\
& \quad=-39.03 \mathrm{cal} \mathrm{K}^{-1} \mathrm{~mol}^{-1}
\end{aligned}
$$


And therefore,

From second law of thermodynamics,

$$
\begin{aligned}
\Delta G_{\text {water }}^{\mathrm{o}} & =\Delta H-T \Delta S \\
\Delta G_{\text {water }}^{\mathrm{o}} & =-68.31+298.15 * 39.03 / 1000 \\
& =-56.7 \mathrm{kcal} / \mathrm{mol}
\end{aligned}
$$

In electrolysis, only the free energy of reaction, $\Delta \mathrm{G}$, can be interchanged with electrical energy at constant temperature and pressure. The electric charge corresponding to the number of moles is indicated in the balanced equation as $\mathrm{nF}$. where $\mathrm{n}$ is the number of electrons and $\mathrm{F}$ is the Faraday constant. When this electrical charge is passed through a potential difference of E volts , then the amount of work would be nFE. The change in the Gibbs free energy is given by equation:

$$
\Delta \mathrm{G}=-\mathrm{nFE}=\text { work --- }(2.4)
$$

From Eq 2.4, E can be calculated as,

$$
\mathrm{E}=-\Delta \mathrm{G} / \mathrm{nF}=\left(56.7 * 10^{3} * 4.18\right) /\left(2 * 9.65 * 10^{4}\right) .(\mathrm{Cal} . \mathrm{J} / \mathrm{cal}) .=-1.23(\text { volts }=\mathrm{J} / \mathrm{C}) .
$$

Hence the minimum voltage needed for conventional water electrolysis for producing hydrogen is 1.23 volts.

\subsection{Electrochemical Gasification of Carbon:}

The electrochemical gasification of carbons was proposed by Coughlin and Farooque [3]. It is a process in which coal and water converts into pure streams of $\mathrm{CO}_{2}$ and $\mathrm{H}_{2}$ separately at the anode and the cathode respectively. The main traits of this process which makes it outstanding amongst the other methods of $\mathrm{H}_{2}$ production are that this reaction takes place at low temperatures (even room temperature) compared to high temperatures used in CG and SMR process. This is due to the electrons provided by the carbon. Otherwise large amounts of thermal energy would be required. The simplicity of this process is due to the fact that it doesn't require any gas 
purification steps making the electrochemical gasification an efficient process for in-house production of $\mathrm{H}_{2}$ gas.

The proposed chemical reactions of electrochemical gasification processes are listed below. These equations below have been postulated focusing only on the carbon in the coal. The two half-reactions (at anode and cathode) to obtain the net balance reaction are shown [3]:

Anode: $\quad \mathrm{C}(\mathrm{s})+2 \mathrm{H}_{2} \mathrm{O}(l) \rightarrow \mathrm{CO}_{2}(\mathrm{~g})+4 \mathrm{H}^{+}+4 \mathrm{e}^{-}$.

Cathode: $\quad 4 \mathrm{H}^{+}+4 \mathrm{e}^{-} \rightarrow 2 \mathrm{H}_{2}(\mathrm{~g})$

Net reaction: $\quad \mathrm{C}(\mathrm{s})+2 \mathrm{H}_{2} \mathrm{O}(l) \rightarrow 2 \mathrm{H}_{2}(\mathrm{~g})+\mathrm{CO}_{2}(\mathrm{~g})$

\subsubsection{Energy Requirements:}

It is known that the Gibbs free energy required for conventional water electrolysis can be calculated using the equation:

$$
\Delta \mathrm{G}=\text {-nFE. }
$$

In the electrochemical gasification of coal, water is the used as a reactant and carbon dioxide is yielded as product. Hence in calculating the energy requirement we can compare it with water electrolysis and the calculations are given below in detail:

$$
\begin{aligned}
\Delta \mathrm{G}(\text { net change required }) & =\Delta \mathrm{G}(\text { product })-\Delta \mathrm{G} \text { (reactants }) \\
= & -94.26\left(\mathrm{CO}_{2}\right)+2(56.7)\left(\mathrm{H}_{2} \mathrm{O}\right)=19.14 \mathrm{kcal} / 2 \mathrm{~mol} \mathrm{H}_{2} \mathrm{O} \\
= & 9.6 \mathrm{kcal} / \text { moles }_{2} \mathrm{O}---\mathrm{Eq}(2.8)
\end{aligned}
$$

Compared to $\Delta \mathrm{G}=56.7 \mathrm{kcal} / \mathrm{mol}$ required for water electrolysis the electrochemical gasification process requires much less energy of only $9.6 \mathrm{kcal} / \mathrm{mole}_{2} \mathrm{O}$. 
The corresponding cell potential required for the coal gasification is:

$$
\begin{aligned}
\mathrm{E}^{0}=-\Delta \mathrm{G} / \mathrm{nF} & =\left(-19.27 * 10^{3} * 4.78 \mathrm{~J}\right) /\left(4 * 9.6 * 10^{4} \mathrm{C}\right)--\mathrm{Eq}(2.9) \\
& =-0.21 \mathrm{~V}
\end{aligned}
$$

This shows that conventional water electrolysis is too energy intensive $\left(E^{0}=-1.23 \mathrm{~V}\right)$ as compared to energy required for the proposed electrochemical carbon gasification which requires only $\mathrm{E}^{0}=-0.21 \mathrm{~V}$.

The above reactions were proposed by Coughlin and Farooque [6] and if true, the energy requirements would be reduced approximately by a factor of six. In the electrochemical gasification process the coal is gasified by reaction with water, but using externally supplied electrons to make the process work at lower voltages therefore avoiding the need of supplying large amounts of thermal energy. However, the practical operating voltages at which they conducted their experiments were between $0.85 \mathrm{~V}$ and $1.0 \mathrm{~V}$ compared to $\mathrm{E}^{0}>2 \mathrm{~V}$ needed for water electrolysis.

\subsection{RESULTS:}

Both water electrolysis and electrochemical gasification experiments were repeated in our laboratory [7]. The experiments were done in a specially designed cell used mainly for the electrolysis. The following figure shows the cell from which the standard potentials for the electrochemical gasification are measured: 


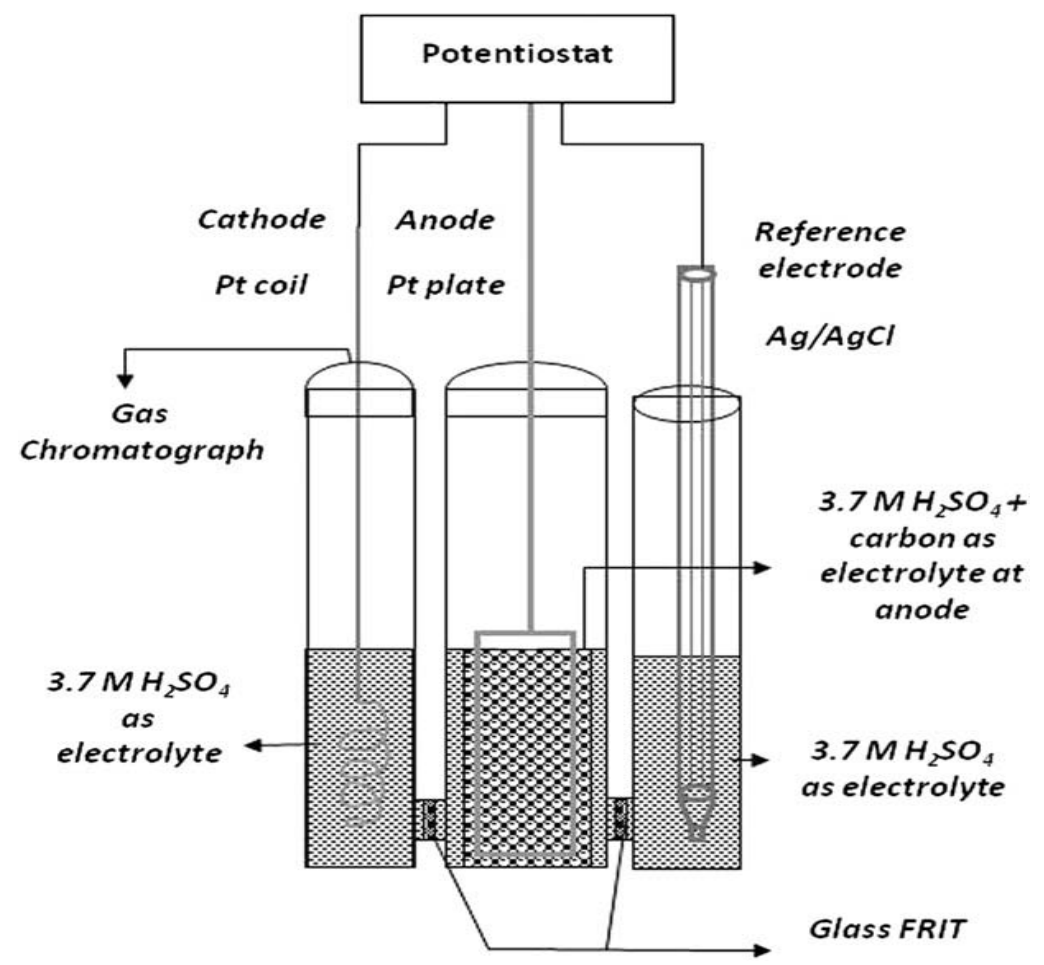

Fig 2.1: Block diagram of the electrochemical cell used in the experiments.

\subsection{Parameters of Interest}

As shown in Fig.2.1, a commercial potentiostat (BAS Model 100B) was used as an voltage and current source for the three electrode cell. The three electrodes are the cathode (working electrode) the anode (auxiliary electrode) and the reference electrode $(\mathrm{Ag} / \mathrm{AgCl})$ in our case). All the voltages are measured with respect to the reference electrode. As voltage is varied, significant current flows between the cathode and the anode at a given constant voltage, but negligible current flows between the working electrode and reference electrode. By international convention, the reference voltage for the standard hydrogen electrode $(\mathrm{SHE})$ reaction $\left(\mathrm{H}^{+}(\mathrm{aq}\right.$, $\left.A=1)+\mathrm{e}^{-} \rightarrow 1 / 2 \mathrm{H}_{2}(g, A=1)\right)$ is taken to be zero. The reference electrode used here was $\mathrm{Ag} / \mathrm{AgCl}$ (Ag wire dipped in $\mathrm{AgCl}$ solution) with redox potential of $0.22 \mathrm{~V}\left(\mathrm{AgCl}(s)+\mathrm{e}^{-} \rightarrow \mathrm{Ag}(s)+\mathrm{Cl}^{-}\right)$. Therefore, to convert the measured voltage $\mathrm{E}(\mathrm{Ag} / \mathrm{AgCl})$ to $\mathrm{E}^{0}(\mathrm{SHE})$, the following equation is used:

$$
\mathrm{E}^{0}(\mathrm{SHE})=\mathrm{E}(\mathrm{Ag} / \mathrm{AgCl})+0.22 \mathrm{~V} . \quad \mathrm{Eq}(3.0)
$$

Thus if potentiostat reads $E=0.60 \mathrm{~V}$, then the equivalent $\mathrm{E}^{0}(\mathrm{SHE})=0.60+0.22=0.82 \mathrm{~V}$. Data shown here are plotted with respect to $\mathrm{E}^{0}(\mathrm{SHE})$. 
The other quantities measured as $\mathrm{E}(\mathrm{Ag} / \mathrm{AgCl})$ is varied are the current $\mathrm{I}_{0}$ flowing in the circuit and $\mathrm{H}_{2}$ produced as measured by the area under $\mathrm{H}_{2}$ peak in the gas chromatograph (more on this in the following chapters). From this, the hydrogen evolution rate $\mathrm{R}_{\mathrm{H}}$ is determined as the area under the $\mathrm{H}_{2}$ peak for a fixed time. The third quantity is calculated as $\mathrm{A}_{\mathrm{H}}=\mathrm{R}_{\mathrm{H}} / \mathrm{E}^{0} \mathrm{I}_{0}$ defined as hydrogen produced for watt-hr of energy used. For determining efficiency, maximum $A_{H}$ is needed for a given but practical $\mathrm{R}_{\mathrm{H}}$.

The following plot in Fig.2.3 shows a comparison of hydrogen production between carbon assisted water electrolysis (CAWE) and simple water electrolysis (WE).

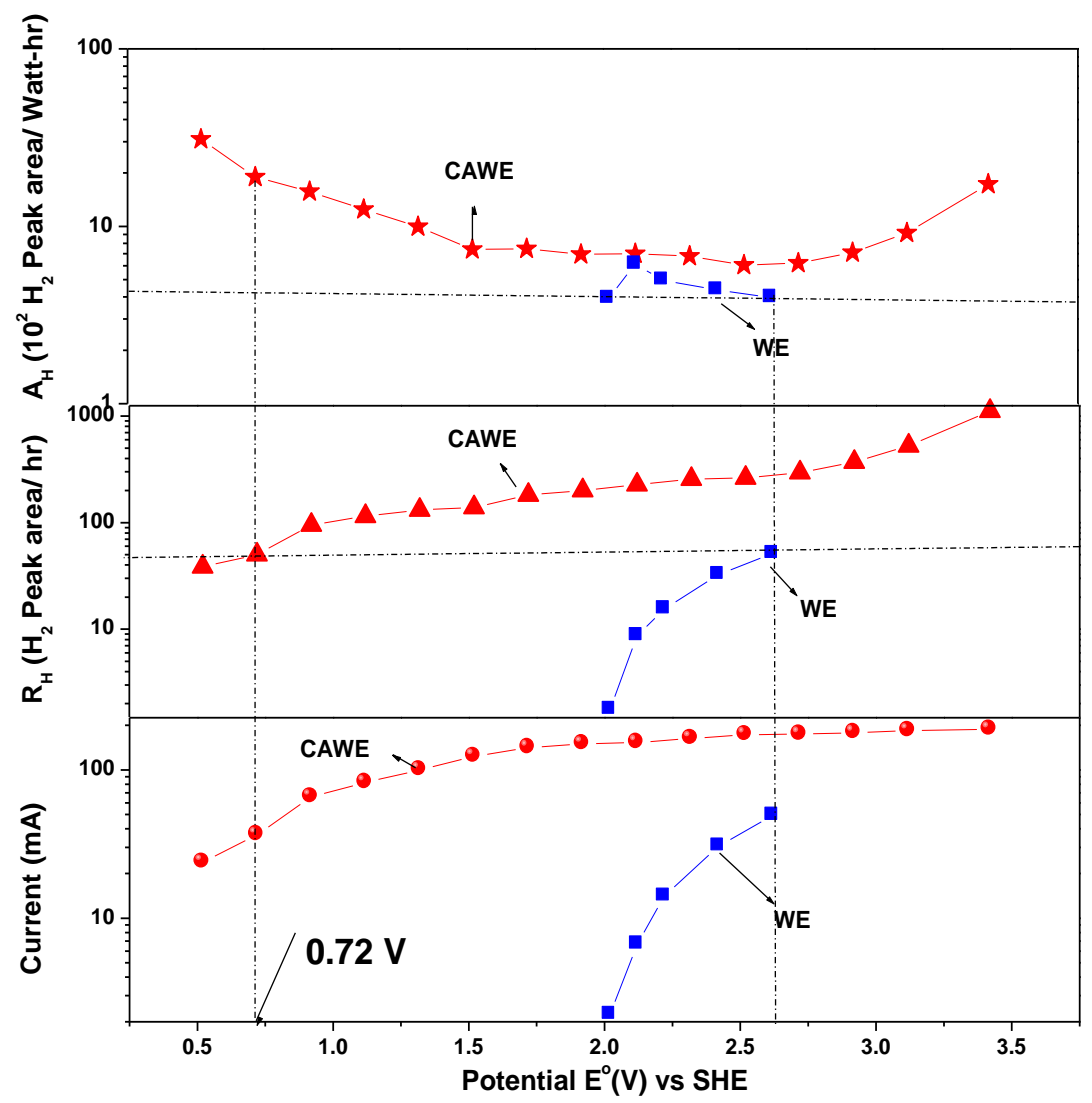

Fig 2.2: Plot showing comparison of hydrogen production between WE and CAWE. 
For water electrolysis, $\mathrm{H}_{2}$ production begins only for $\mathrm{E}^{0}>2 \mathrm{~V}$, whereas for the CAWE process using carbon $\mathrm{BP} 2000, \mathrm{H}_{2}$ production is observed at $\mathrm{E}^{0} \sim 0.5 \mathrm{~V}$. To make a meaningful comparison, consider the horizontal line drawn in Fig 2.2 for $\mathrm{R}_{\mathrm{H}} \mathrm{vs}$. $\mathrm{E}^{0}$ plot for a fixed $\mathrm{R}_{\mathrm{H}}$. This comparison shows that same $\mathrm{R}_{\mathrm{H}}\left(\mathrm{H}_{2}\right.$ evolution rate) is observed at $\mathrm{E}^{0}=0.72 \mathrm{~V}$ in $\mathrm{CAWE}$ as for $\mathrm{E}^{0}=2.65 \mathrm{~V}$ in water electrolysis. In the plot of $\mathrm{A}_{\mathrm{H}} \mathrm{vs}$. $\mathrm{E}^{0}$, the magnitude of $\mathrm{A}_{\mathrm{H}} \sim 20$ units at $\mathrm{E}^{0}=0.72 \mathrm{~V}$ in CAWE as compared to $\mathrm{A}_{\mathrm{H}} \sim 4$ units at $\mathrm{E}^{0}=2.65 \mathrm{~V}$ in WE. So in CAWE using BP2000 carbon, a factor of about 20/4 $=5$ in energy efficiency is obtained over ordinary water electrolysis yet providing the same $\mathrm{H}_{2}$ evolution rate. Similar comparison will be made using the HTP biomass samples. 


\section{CHAPTER 3 EXPERIMENTAL PROCEDURES}

\subsection{Synopsis:}

In this chapter, equipment and samples used in the experiments and details of the experimental procedures are presented. Cellulosic biomass usually requires physical or chemical treatment to disrupt lignin, to dissolve hemicellulose and to increase accessibility of cellulose to hydrolysis. In general, hemi-cellulose and cellulosic components of biomass decompose at about $300^{\circ} \mathrm{C}$ compared to about $600^{\circ} \mathrm{C}$ for the decomposition of coals. The ash components of biomass (e.g. chlorine, sulfur and alkali compounds and silica) can vary from a few percent in the case of woody biomass to about $20 \%$ for some agricultural biomass. The moisture content of biomass can be as high as $50 \%$. These considerations along with the difficulty of grinding biomass because of its fibrous nature makes coal-biomass co-processing for power generation and syngas production quite problematic. For these reasons, we undertook the new process of Hydrothermal Pretreatment (HTP) of biomass samples to make their chemical and physical characteristics more coal-like before coal-biomass co-processing is carried out.

In this regard various pretreatment technologies have been developed including dilute acid, ammonia steam-explosion; hydrothermolysis etc. In a recent review, Kumar et al [1] have summarized the results obtained in these experiments so far using different pretreatment processes. Of these hydrothermal treatments of biomass samples was found effective as it minimizes formation of toxic products during pretreatment.

\subsection{Sample Preparation:}

The samples investigated in this work include a sample of crystalline cellulose purchased from Alfa-Aesar and wood sawdust sample collected from our wood machine shop. The hydrothermal pretreatment (HTP) was carried out in an autoclave (Parr Instruments) (Fig 3.1) by using a 10 grams of the sample with $50 \mathrm{~mL}$ of deionized water, sealing the autoclave and heating it for various times at $200^{\circ} \mathrm{C}$ and $500 \mathrm{psi}$ of pressure generated from the evaporation of water. 


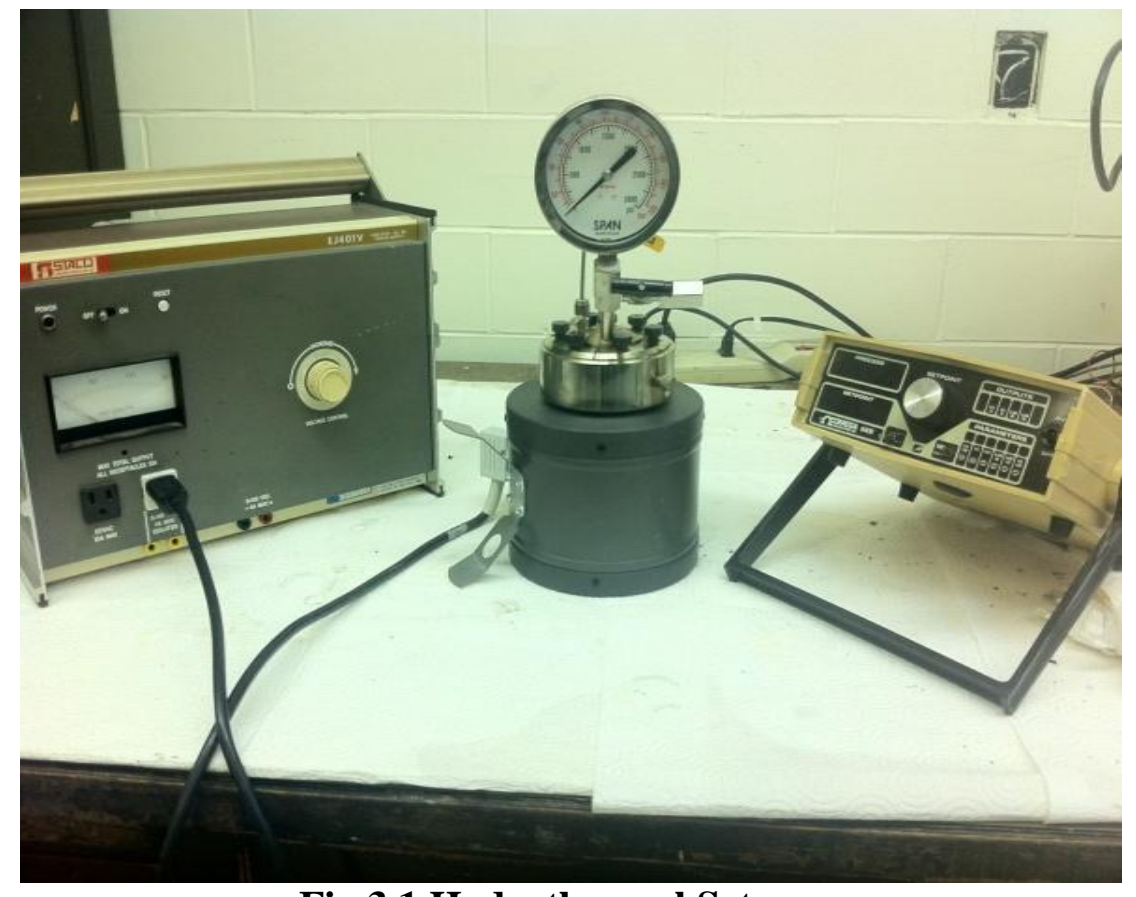

Fig 3.1 Hydrothermal Setup:

The autoclave was opened after cooling it to room temperature and the solid product was separated from the liquid by centrifugation. The product, black in color, was paper-dried overnight and used as such in the experiments. Fig 3.1 shows the comparison of samples before and after of hydrothermal processing.

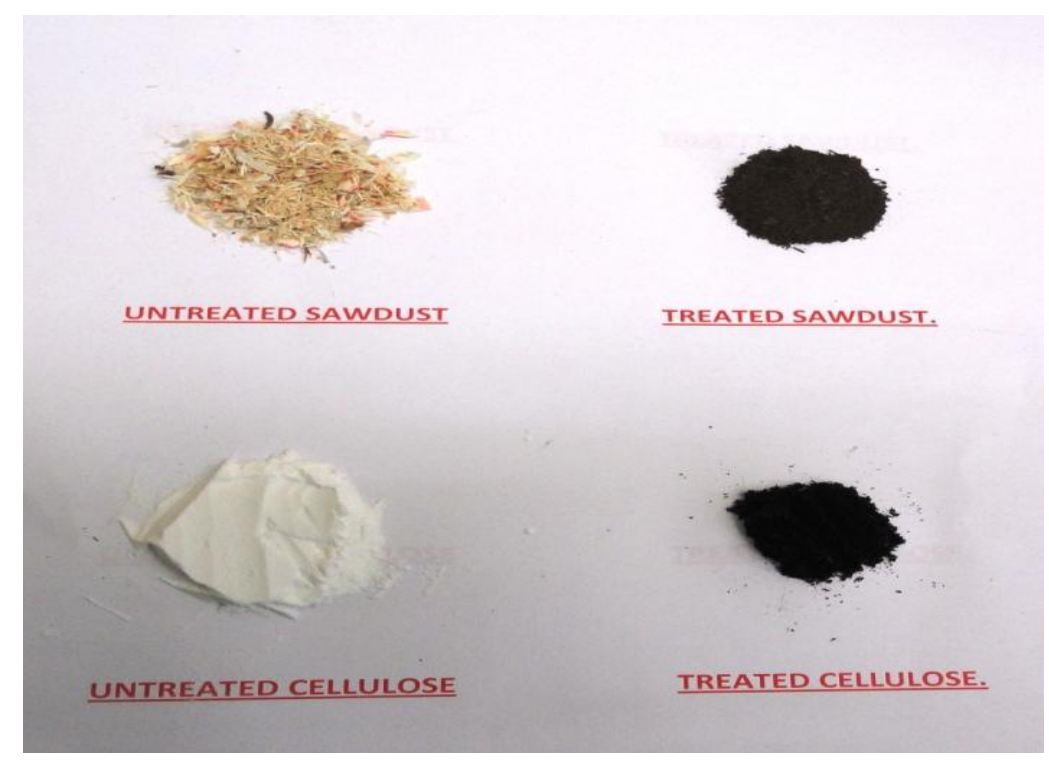

Fig3.2 Comparison of sample before and after HTP

In Fig.3.2 the treated and untreated samples for both microcrystalline cellulose and sawdust are been compared. These samples were characterized using scanning 
electron microscopy (SEM): The SEM micrographs of the original biomass sample and the products from HTP are taken to compare their particle sizes.X-ray diffraction(XRD) Room temperature wide-angle XRD scans of the four samples are taken to compare the sharpness of the Bragg lines and Thermogravimetric analysis (TGA) was done to determine their decomposition temperatures. All the results and studies on these are presented in the following chapters.

\subsection{Experimental Setup for Electrochemical Experiments:}

A three-electrode cell used for the electrochemical production of hydrogen is shown in Fig.3.3 below. The compartment in the center is the anode and it consists of a Pt plate, whereas the compartment to the left side is the cathode and it consists of a Pt coil. The compartment to the right is the reference electrode. The three compartments have the electrolyte, $3.7 \mathrm{M} \mathrm{H}_{2} \mathrm{SO}_{4}$ since it has been found to give the best performance for an acidic medium [5]. The anode is the working electrode made of platinum plate (working area $6.8 \mathrm{~cm}^{2}$ ) attached with a platinum wire to allow electrical connections.
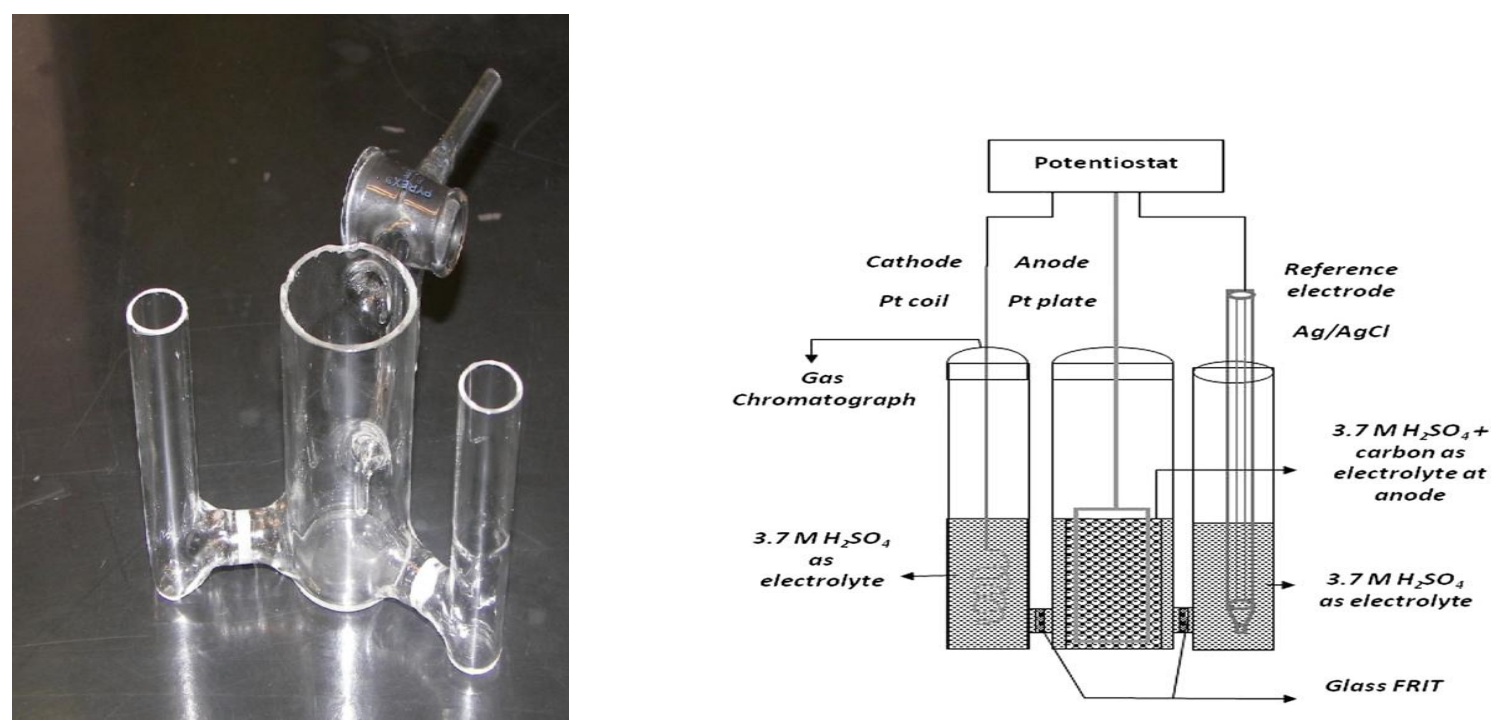

Fig.3.3 Photograph and schematic diagram of three-electrode cell used in electrochemical experiments. 
The cathode compartment which contains only 3.7 $\mathrm{M}$ sulfuric acid as the electrolyte is the counter electrode. This counter electrode is a platinum coil having a surface area of $2.5 \mathrm{~cm}^{2}$. The third compartment consists of the reference electrode with $3.7 \mathrm{M}$ sulfuric acid as the electrolyte. A standard $\mathrm{Ag} / \mathrm{AgCl}$ (Metrohm 6.0726.100) electrode was used as reference electrode. There are two glass frit between the anode/cathode and the anode/reference to prevent any gases from entering into the cathode or reference and also to prevent any biomass particles from entering into the cathode or reference compartments. The electrodes are connected to the leads of the potentiostat (BAS model $100 \mathrm{~B}$ ) to power the cell. The main purpose of using the potentiostat is that it stabilizes the potential between the cathode and anode with respect to the reference. The evolved $\mathrm{H}_{2}$ gas was monitored by a gas chromatograph (SRI model 8610C). Fig. 3.4 shows the electrochemical setup along with the BAS potentiostat.

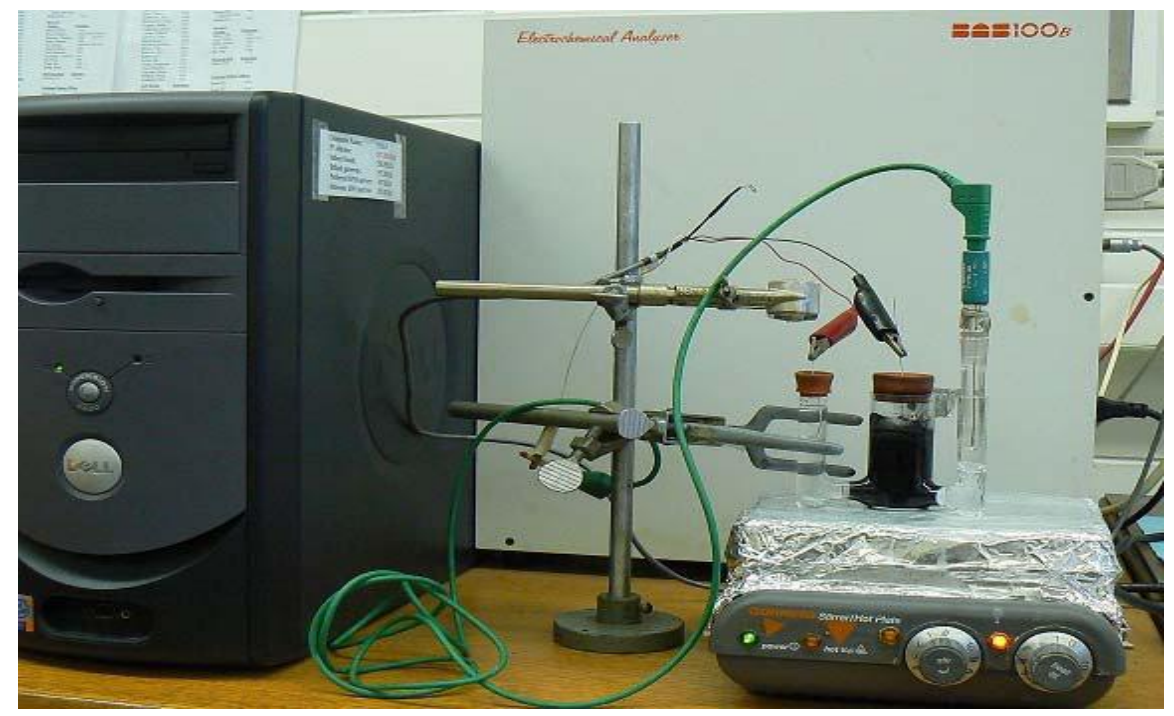

Fig 3.4: Electrochemical setup along with potentiostat used in the experiments.

\subsection{GAS CHROMATOGRAPH:}

The 8610C Multi gas analyzer \#2 GC supplied by SRI instruments was used to detect the gases evolved in the cathode and anode compartments of the cell (Fig.3.4). The 8610 C GC is a Multiple Gas Analyzer capable of separating a wide variety of peaks. This gas analyzer can detect gases like $\mathrm{H}_{2}, \mathrm{O}_{2}, \mathrm{~N}_{2}$, methane, $\mathrm{CO}, \mathrm{CO}_{2}$ etc. The carrier gas used was ultra high purity nitrogen. There are two separate carrier gas flows, each regulated by electronic 
pressure control through the software (peak simple). The GC contains a Thermal Conductivity Detector (TCD)[11] and two columns viz. Molecular sieve 13X \& Hayesep-D. The carrier gas should flow through Molecular sieve 13X \& Haysep-D with a constant pressure of 20psi and 8psi respectively. The gas that evolves from any one compartment of the electrochemical cell is injected through the sampling valve using an airtight syringe. When the gas is injected into the GC we get some peaks and to separate such a wide variety of peaks, the gas chromatograph turns on the carrier gas flow to each column at different times during the run. This allows the molecular sieve column to complete the separation of $\mathrm{H}_{2}, \mathrm{O}_{2}, \mathrm{~N}_{2}$, methane, $\mathrm{CO}$, at which point the molecular sieve is turned off and the Hayesep-D is turned on. The Haysep-D column then separates all compounds in the C1-C6 range. A capillary column in parallel with the Haysep-D can also be useful for separating the hydrocarbons. An event table determined the ON and OFF of either of the carriers. The hydrogen and $\mathrm{CO}$ are detected by the molecular sieve column and $\mathrm{CO}_{2}$ is detected by the Haysep-D column[12]. The run was carried for duration of 8-14 minutes with a retention time of $\sim 0.5 \mathrm{~min}$ for hydrogen, $\sim 6.87 \mathrm{~min}$ for $\mathrm{CO}$ and $\sim 8.33 \mathrm{~min}$ for $\mathrm{CO}_{2}$ at an isothermal column oven temperature of $120^{\circ} \mathrm{C}$. Fig. 3.5 is the picture of the $8610 \mathrm{C}$ gas chromatograph.

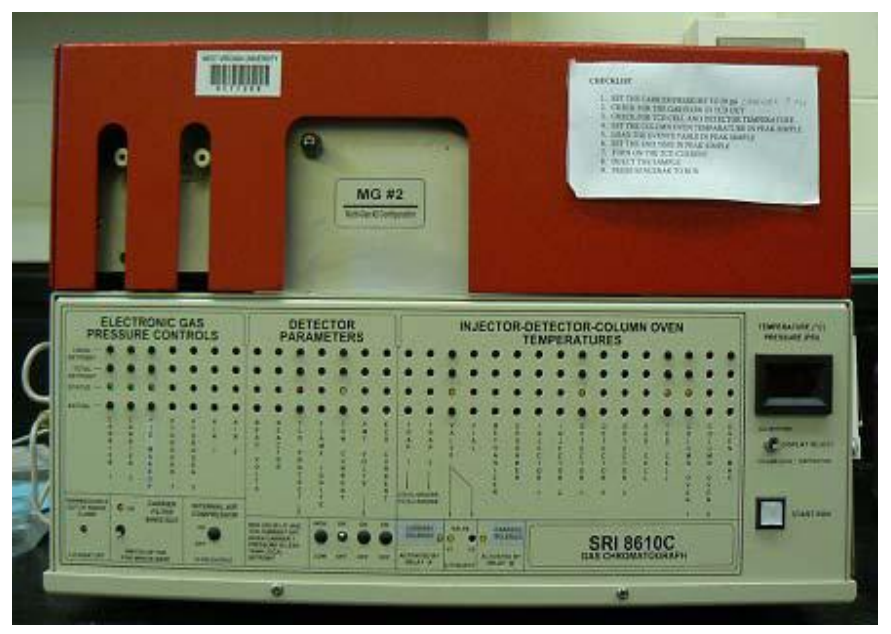

Fig 3.5: GAS CHROMATOGRAPH 8610C 


\subsection{EXPERIMENTAL PROCEDURES:}

In each experiment for a particular applied $E^{\circ}$, the time $t_{\mathrm{H}}$ needed to electrolyze approximately the same amount of the electrolyte in the cathode cell was measured, while simultaneously recording the current $\mathrm{I}_{0}$ (with the BAS100 B). The three compartments of the cell are filled with $3.7 \mathrm{M} \mathrm{H}_{2} \mathrm{SO}_{4}$ electrolyte for every experiment. Sample is added to the anode compartment and magnetic stirrers are placed in the anode and cathode compartments. The electrodes are placed in the three chambers and the leads of the potentiostat which are colored black, red and green are connected to the anode, cathode and the reference electrodes respectively. Using the potentiostat software which is interfaced to it through the computer, a certain potential is applied to the electrodes. At the onset of the applied potential, the hydrogen starts to evolve at the cathode which is indicated by the formation of bubbles in the cathode compartment (explained above). The cathode compartment is sealed with a rubber cork to avoid any loss of $\mathrm{H}_{2}$. Then as time goes on, pressure is built in the cathode compartment which will lead to a decrease in the level of the electrolyte. Once the level decreases by $1 \mathrm{ml}$ (this is always kept the same), a fixed volume of the gas $(2 \mathrm{ml})$ produced in the cathode is then injected by a syringe into the GC column and the area under the $\mathrm{H}_{2}$ peak is noted. The amount of current $\mathrm{I}_{0}$ will be measured by the data obtained from the potentiostat. This way, for each $E^{\circ}$, we obtain approximately the same area but different $t_{H}$ and $I_{0}$. Then normalized time $\left(t_{H}\right)$ for exactly the same peak area (we chose 3000 units) was calculated for each $E^{\circ}$. The value of $t_{\mathrm{H}}$ at a particular potential $\mathrm{E}^{0}=\left((\right.$ time $(\mathrm{hr}) \mathrm{x} 3000) /$ peak area) $\left(\mathrm{Hr} / \mathrm{H}_{2}\right)$. Thus in the experiments for every $E^{0}$ (in the range of 0.54 to $3.42 \mathrm{~V}$ ), the time $t_{H}$ required to produce exactly the same amount of hydrogen at the current $I_{0}$ in the circuit are determined. From those values of $I_{0}$ and $t_{\mathrm{H}}$ the following quantities are calculated: (i). Current at every potential value $\mathrm{I}_{0}(\mathrm{~mA})$; (ii) Rate of hydrogen evolution per hour $R_{H}$ (amount of $H_{2} / H r$ ) $=1 / t_{h}$, where $t_{h}$ is the time taken to produce the same amount (3000 units) of hydrogen and (iii). $A_{H}=R_{H} / I_{0} E_{0}$ representing the amount of hydrogen produced per $\mathrm{W} h$ of energy used. The potentials listed throughout the work are with respect to a standard hydrogen electrode (SHE) and so corrected for $E^{0}=0.22 \mathrm{~V}$ for $\mathrm{Ag} / \mathrm{AgCl}$. As an example, if $\mathrm{E}=0.60 \mathrm{~V}$ is measured by the potentiostat with respect to $\mathrm{Ag} / \mathrm{Agcl}$, then $\mathrm{E}^{0}=$ $0.60+0.22=0.82 \mathrm{~V}(\mathrm{SHE})$ is the magnitude listed in the graphs. 
In comparing the efficiencies of different samples and processes for $\mathrm{H}_{2}$ production, maximum values of the $\mathrm{H}_{2}$ evolution rate $\mathrm{R}_{\mathrm{H}}$ and $\mathrm{A}_{\mathrm{H}}$ at a given $\mathrm{E}^{0}$ are compared. This way the best operating $\mathrm{E}^{0}$ to have realistic evolution rate $\mathrm{R}_{\mathrm{H}}$ yet producing more hydrogen per watt-hr of energy used are determined. These results and discussion are presented in the next chapter. 


\section{CHAPTER 4 \\ RESULTS AND DISCUSSION}

\subsection{Overview:}

In this chapter, results on the electrochemical production of hydrogen using untreated cellulose and wood sawdust as well as hydrothermal pretreated (HTP) wood sawdust and microcrystalline cellulose are reported. For better understanding of these compounds, the physical and chemical characteristics of untreated commercial crystalline cellulose and sawdust are compared with those of HTP samples obtained after pretreatment in a reactor at $200^{\circ} \mathrm{C}$ and 500psi pressure. X-ray diffraction, SEM (scanning electron microscope) analysis and thermogravimetric analysis (TGA) are used for characterization of the samples. Finally, the results obtained for the biomass compounds are compared with results from water electrolysis (WE) and carbon-assisted water electrolysis (CAWE).

\subsection{Hydrothermal Pretreatment (HTP):}

In our first experiment using HTP, we heated both the wood sawdust and microcrystalline cellulose samples for one hour at $250^{\circ} \mathrm{C}$ without recording the temperature pressure conditions as a function of time. Since this sample produced very favorable results in hydrogen production as discussed later, these samples of HTP cellulose and wood biomass were examined by SEM by our colleague James Poston at NETL.

During subsequent HTP experiments on crystalline cellulose for $200^{\circ} \mathrm{C}$, for three different times of $15 \mathrm{~min}, 30 \mathrm{~min}$ and $1 \mathrm{hr}$, the temperature-pressure conditions were monitored as a function of time. The plots of temperature vs. time and pressure vs. time are shown in Fig 4.1. It is noted that in all cases, it took about $50 \mathrm{~min}$ for the temperature to reach $200^{\circ} \mathrm{C}$ and is takes nearly equivalent of time for the cool-down process after maintaining the temperature of $200^{\circ} \mathrm{C}$ for $15 \mathrm{~min}, 30 \mathrm{~min}$ and $1 \mathrm{hr}$ duration. For the 15 minute heating, the maximum pressure reached was about 150 psi. For the longer duration of 30 min heating, the maximum pressure 
was almost 500 psi and for 60 min heating, the corresponding value was 600 psi. The drop in pressure with heating turned off is quite rapid. These different conditions had been taken into account in discussing the results obtained with these samples on the electrochemical hydrogen production. SEM studies on these samples have not been taken though both XRD and hydrogen experiments were done and are discussed further in the chapter.

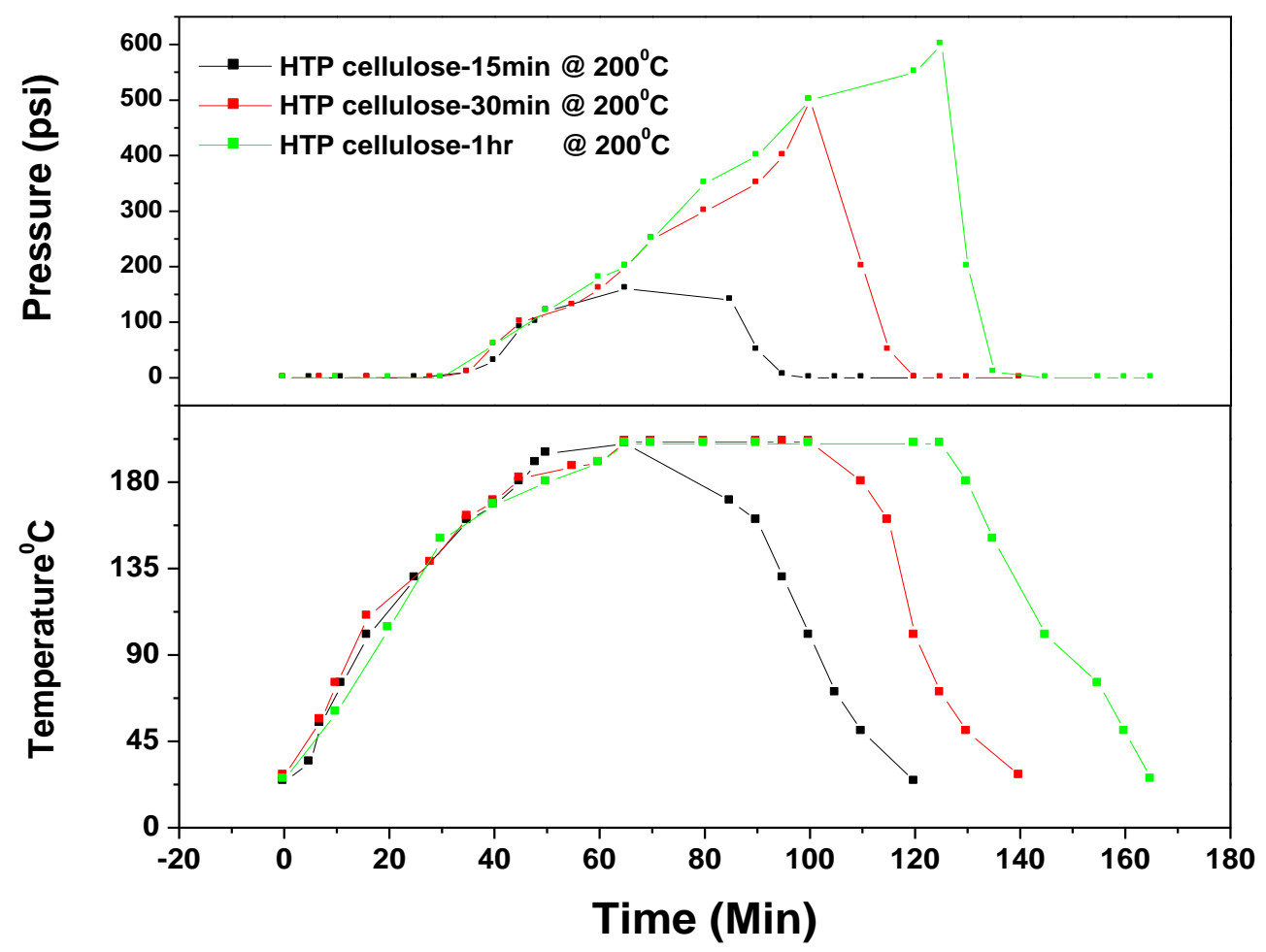

Fig 4.1 Plots of changes in pressure and temperature vs. time during HTP. 


\subsection{X-ray diffraction studies:}

X-ray diffraction (XRD) patterns of the HTP samples and parent samples of both microcrystalline cellulose and wood sawdust are taken mainly to study the crystallinity of the particles. Fig 4.2 shows the XRD results for these samples which had been treated at $250^{\circ} \mathrm{C}$. Later we also compare the XRD samples treated at $200^{\circ} \mathrm{C}$ (as mentioned earlier).

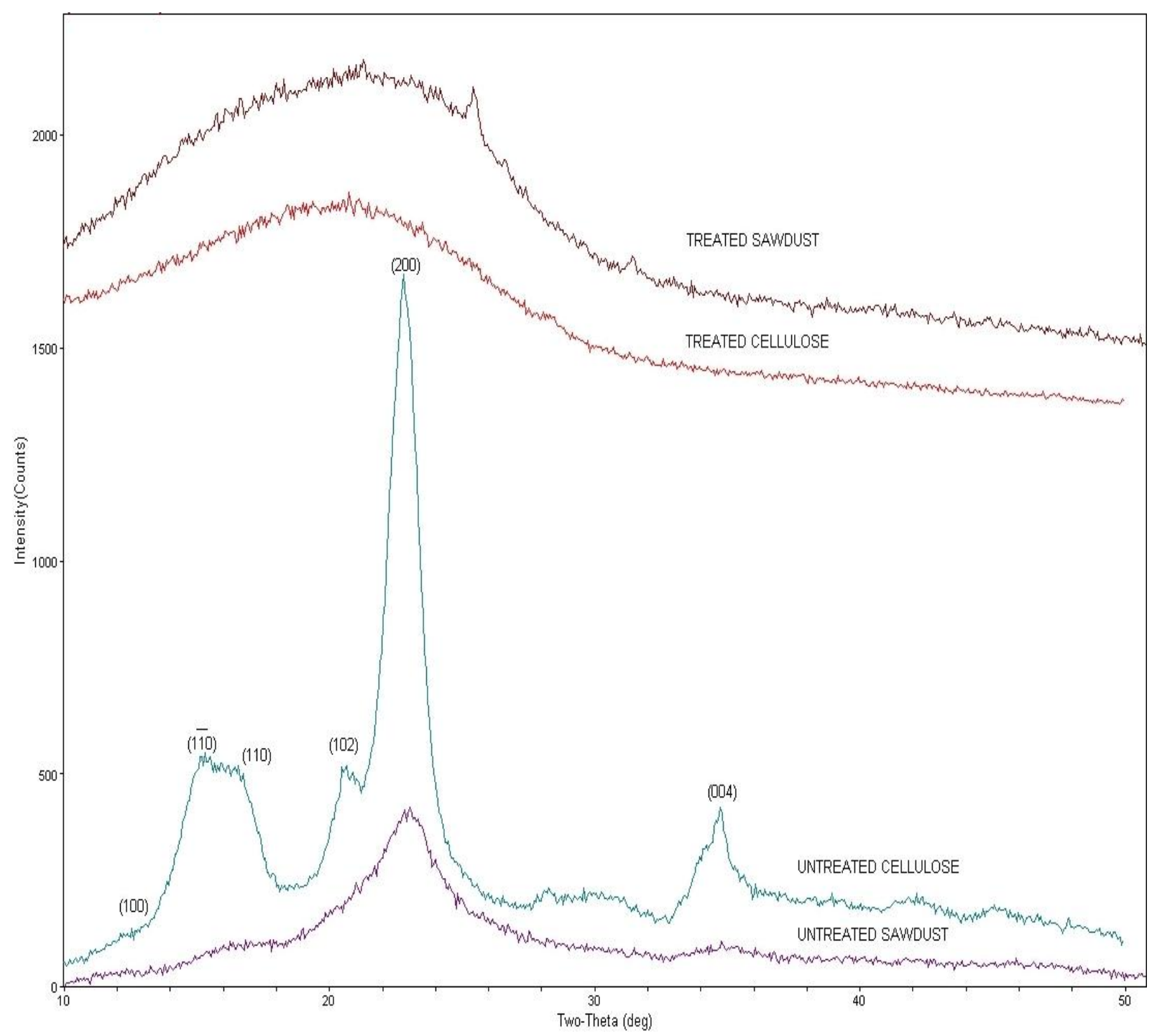

Fig 4.2 Comparison of XRD patterns of HTP produced biomass with the parent biomass samples. 
It is clearly seen from Fig 4.2 that, the parent samples show the crystalline peaks of cellulose. However all these Bragg peaks are missing in the HTP samples. Instead only a broad peak is observed suggesting loss of crystallinity in HTP samples. This loss of crystallinity of the samples is the likely reason that these samples to produce hydrogen more efficiently as shown later from the results of hydrogen experiments. We also did XRD on the $15 \mathrm{~min}, 30 \mathrm{~min}$ and $1 \mathrm{hr}$ samples at $200^{\circ} \mathrm{C}$ and these results are shown in Fig 4.3 below. This plot shows that the $15 \mathrm{~min}$ and 30 min samples do not show required amount of loss of crystallinity for producing hydrogen whereas the $1 \mathrm{hr}$ sample at $200^{\circ} \mathrm{C}$ was comparable with the $1 \mathrm{hr}$ sample at $250^{\circ} \mathrm{C}$. Hence we can anticipate that the temperature of $200^{\circ} \mathrm{C}$ with $1 \mathrm{hr}$ processing time would be sufficient for the HTP process to produce hydrogen efficiently.

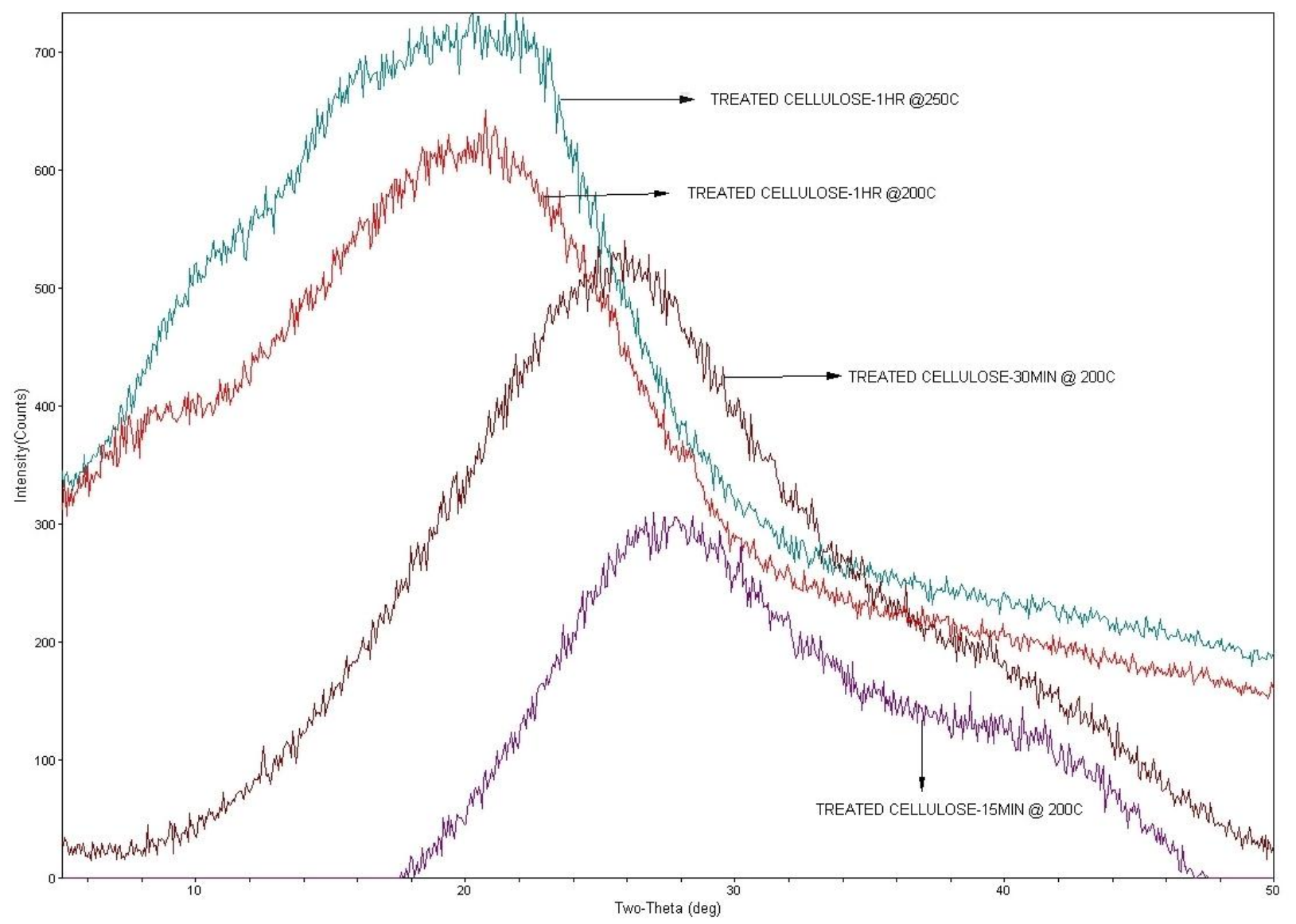

Fig 4.3 Comparison of XRD patterns of HTP samples at $15 \mathrm{~min}, 30 \mathrm{~min}$ and 1 hour at $200^{\circ} \mathrm{C}$ with HTP sample at 1 hour-250 C. 


\subsection{SEM analysis:}

SEM (Scanning electron microscope) micrographs of the biomass samples, done by James Poston at NETL are presented in Fig 4.4 for the microcrystalline cellulose and in Fig 4.5 for the woody sawdust at $250^{\circ} \mathrm{C}$.

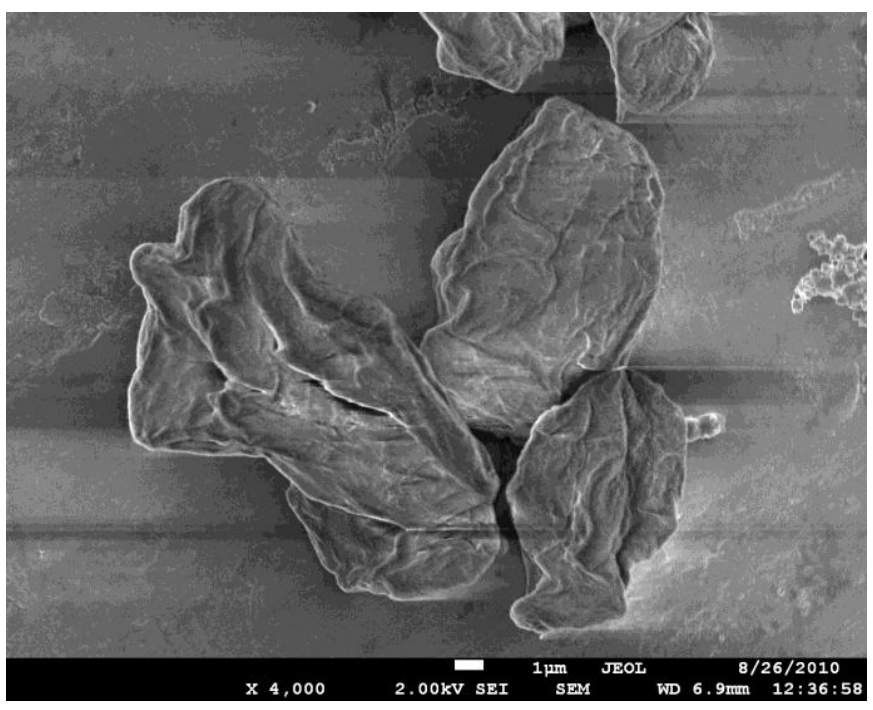

Fig. 4.4(a): SEM micrographs of untreated cellulose Average particle size $=11,824 \times 6,309 \mathrm{~nm}$

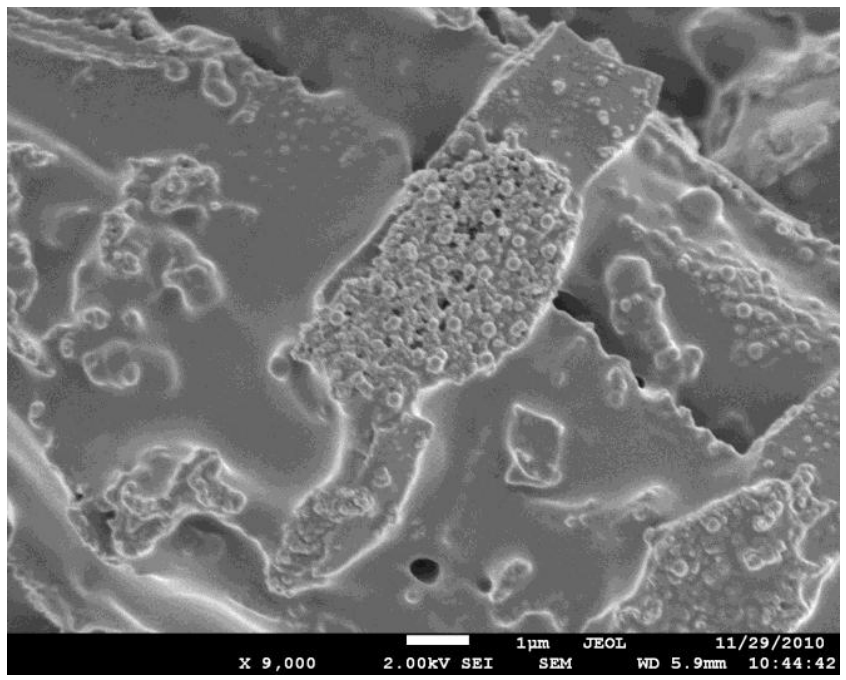

Fig. 4.5(b): SEM micrographs of HP treated sawdust Particle size $=10,186 \times 3,051 \mathrm{~nm}$

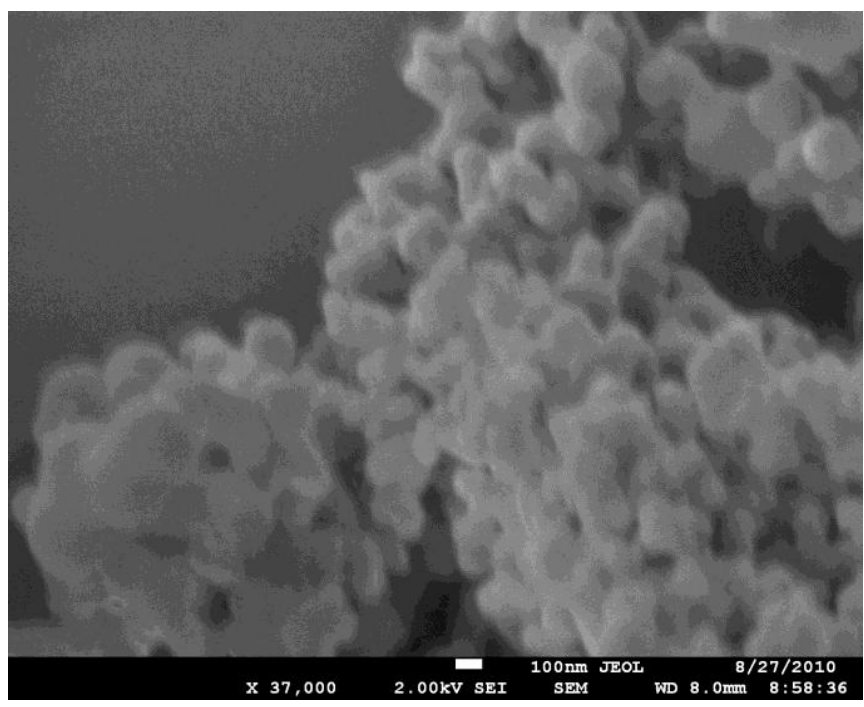

Fig. 4.4(b): SEM micrographs of HP treated cellulose; Average particle size $=208 \times 208 \mathrm{~nm}$

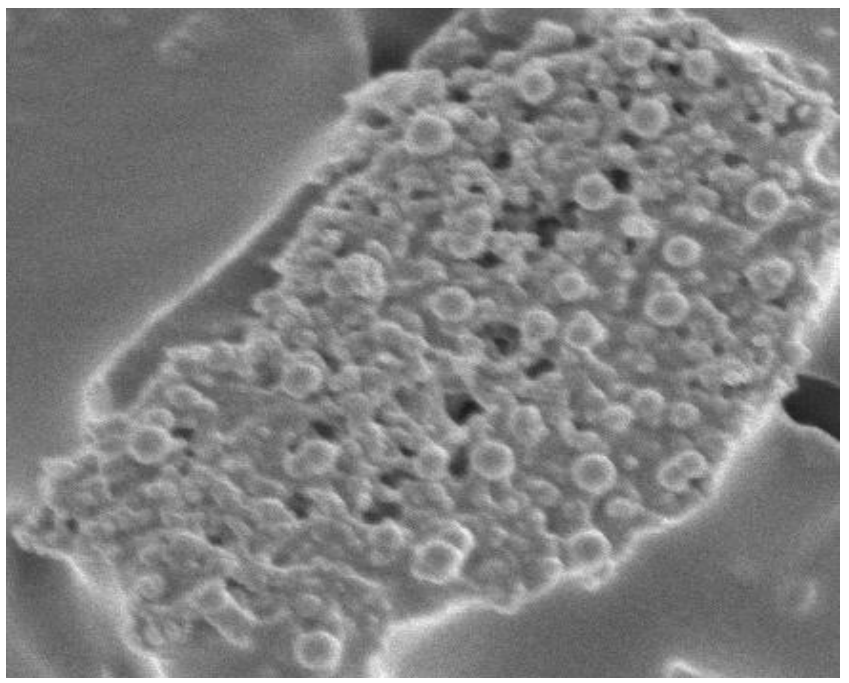

Fig.4.5(c): Enlarged SEM view of HP treated sawdust Particle size $=249 \times 248 \mathrm{~nm}$ 
For the untreated crystalline cellulose purchased from Alfa-Aesar, the particle sizes are about $12 \times 6 \mu \mathrm{m}$ but after HTP, the particle size is reduced to about 1/50 of the original size i.e. about $210 \mathrm{~nm}$. For the untreated sawdust, the size of the particles was about $0.5 \mathrm{~mm} \times 3 \mathrm{~mm}$. After HTP treatment, two distinct sizes are noticed: smaller particles of about $250 \mathrm{~nm}$ diameters, Fig.4.5(c), sitting on top of larger particles of size about $25 \mu \mathrm{m} \times 14 \mu \mathrm{m}$. It is very likely that source of the smaller particles is cellulose and hemi-cellulose and that of the larger particles is lignin. Our reasoning for this assignment is that during the $250 \mathrm{C} \mathrm{HTP}$ processing, lignin with the higher decomposition temperature is essentially unaffected and it is the source of the larger particles. The fact that the size of the smaller particles in the HTP processed sawdust is nearly the same as in HTP processed crystalline cellulose confirms the origin of the smaller particles to be cellulose.

\subsection{Thermo-gravimetric analysis (TGA):}

Thermal Gravimetric Analysis (TGA) is a simple analytical technique that measures the weight loss of a material as a function of temperature. When materials are heated, they can lose weight from a simple process such as drying, or from chemical reactions that liberate gasses. The measurement is normally carried out in air or in an inert atmosphere, such as Helium or Argon, and the weight is recorded as a function of increasing temperature. A derivative weight loss curve can be used to determine the point at which weight loss is most apparent. The point at which the peak appears is considered as the oxidation temperature of that material implying that material will get oxidized at that particular temperature.

In most cases, TGA analysis is performed in a particular atmosphere (air or oxygen and inert gases like argon, helium etc) with a linear increase in temperature. The temperature range in which the TGA should operate is selected so that the sample weight is observed in a specific known temperature range, implying that all chemical reactions are completed (i.e., the entire sample is burnt off leaving behind the impurities). This approach provides two important numerical pieces of information, the impurities in a sample (final mass) and oxidation temperature (To). The oxidation temperature is the difference of two temperatures $T_{i}$ and $T_{f} . T_{i}$ is 
the temperature at which the oxidation begins i.e. the point where the weight of the sample starts to decrease gradually and $\mathrm{T}_{\mathrm{f}}$ is the temperature at which the oxidation is assumed to be completed where the weight of the sample reaches a nearly stable value. The difference of these two would give us the exact oxidation temperature of a particular sample. Fig. 4.6 is the picture of the TGA system used.

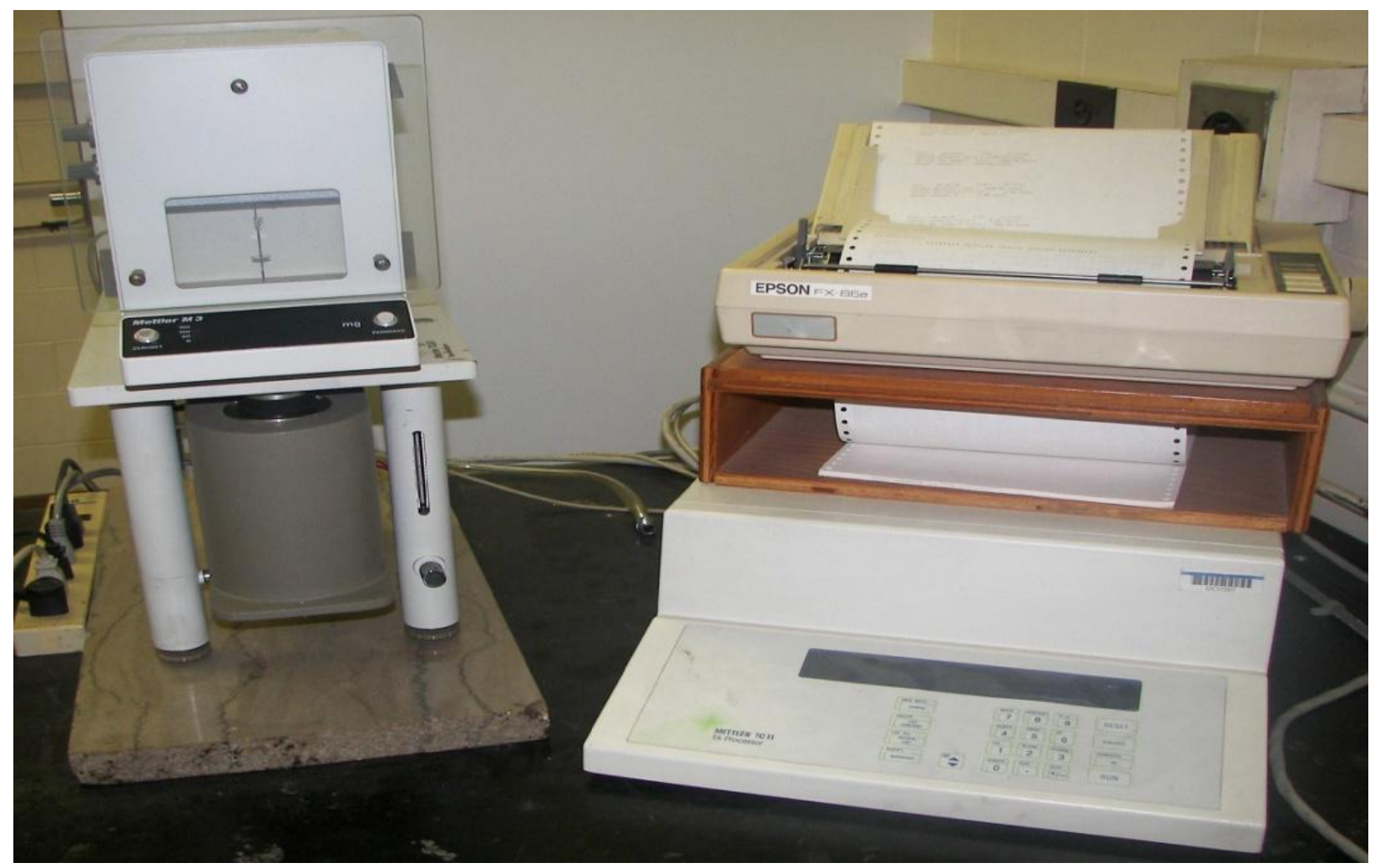

Fig.4.6: Picture of the Thermal Gravimetric Analysis system.

TGA measurements on these samples were also studies and are shown in Fig 4.7. The treated cellulose and wood sawdust at $250^{\circ} \mathrm{C}$ are plotted and were almost comparable with the coal called Illinois \# 6 proving the sample to be more coal like when treated. The small particle size obtained after HTP along with the coal like TGA behavior of the HTP samples suggest that HTP biomass samples are quite suitable for coal-biomass co processing in the thermal plants. In the next section, we also plotted the TGA results of our microcrystalline cellulose sample treated for $15 \mathrm{~min}, 30 \mathrm{~min}$ and 1 hour at $200^{\circ} \mathrm{C}$ 


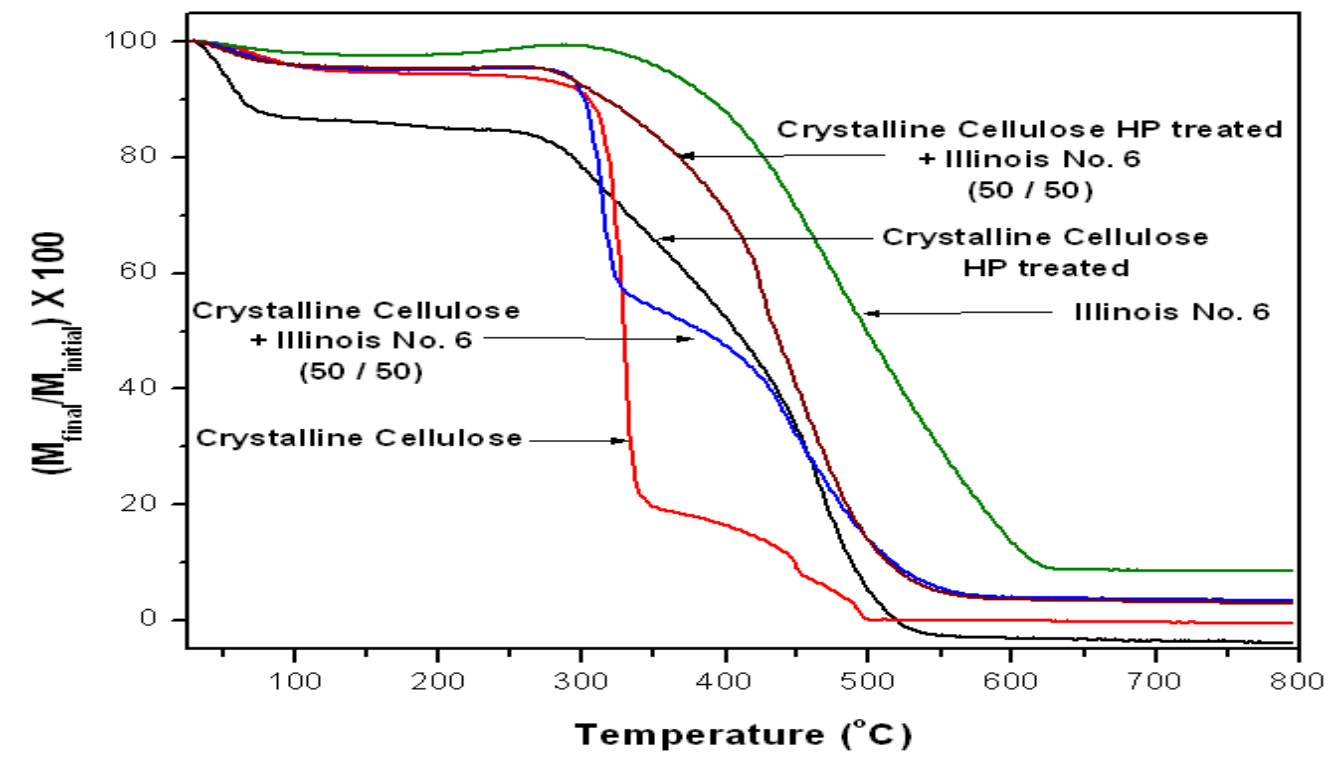

Fig.4.7. TGA measurements on coal biomass samples treated at $250^{\circ} \mathrm{C}$

In Fig 4.8, TGA measurements of the HTP cellulose- 15 min, 30 min and 1 hour samples at $200^{\circ} \mathrm{C}$ are plotted. It is clear that the $15 \mathrm{~min}$ and $30 \mathrm{~min}$ HTP samples are quite different from that of 1 hour HTP sample. Also their decomposition temperatures have been considerably lowered as compared to that of the parent cellulose however, the TGA behavior of the 1 hour HTP- $200^{\circ} \mathrm{C}$ sample is almost the same as that of 1 hour- $250^{\circ} \mathrm{C}$ sample.

These results from TGA are very consistent with those obtained with XRD of these samples. These differences in the nature of the HTP treated samples for different times are also reflected in their efficiencies for producing hydrogen. These results are presented next. 


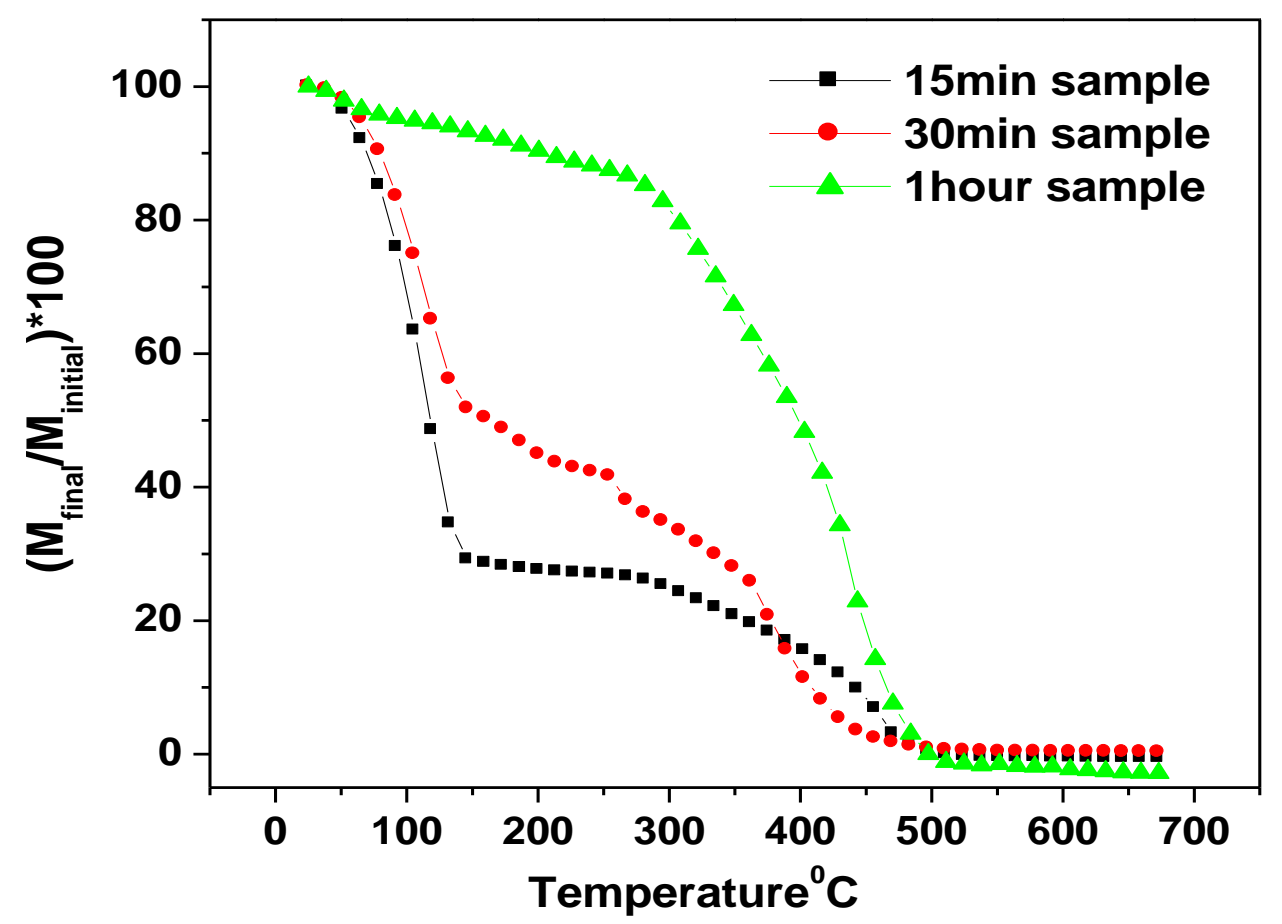

Fig4.8 TGA behavior of the biomass samples at $200^{\circ} \mathrm{C}$.

\subsection{Electrochemical Production of Hydrogen:}

\subsubsection{Time dependence with HTP cellulose at $250^{\circ} \mathrm{C}$ :}

In this section we discuss about the time dependence of the HTP cellulose sample at $250^{\circ} \mathrm{C}$. This time dependence is important because it is been observed that when performing electrochemical experiments of producing hydrogen the sample was getting used up with elapsed time. The results in Fig 4.9 showing time dependence of the current at two operating voltages $\mathrm{E}^{\mathrm{o}}=1.72 \mathrm{~V}$ and $2.22 \mathrm{~V}$. 


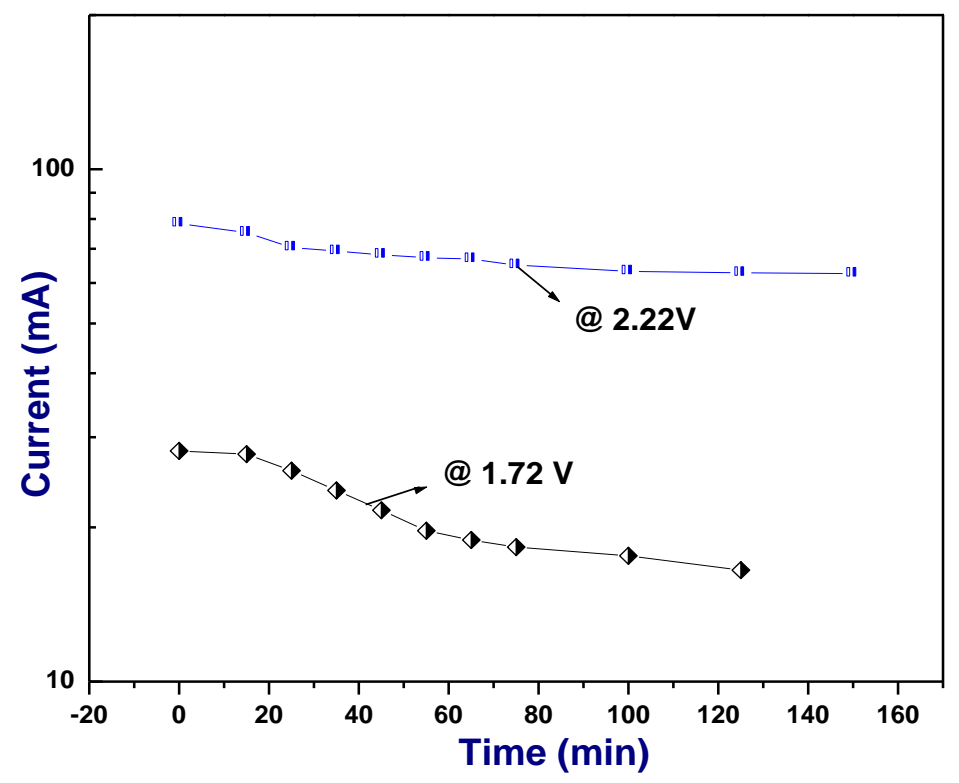

Fig 4.9 Time dependence plot of the current for HTP cellulose treated at $250^{\circ} \mathrm{C}$.

It is seen from the graph that with increase in time there is a decrease in the current at both lower as well as the higher potentials. Hence in all our later experiments, we made sure that a new sample was added to the anode in the electrolyte cell at every potential value (i.e. $0.08 \mathrm{gm} / \mathrm{cm}^{3}$ of cellulose in $50 \mathrm{ml}$ of $3.7 \mathrm{M} \mathrm{H}_{2} \mathrm{SO}_{4}$ at anode). In the next section, we show the results on efficiency of hydrogen production using the untreated samples, the HTP cellulose samples at $200^{\circ} \mathrm{C}$ and $250^{\circ} \mathrm{C}$ and presented and compared with the results obtained using carbon BP2000.

\subsubsection{Results obtained with untreated and HTP- $250^{\circ} \mathrm{C}$ biomass samples:}

In this section results of the electrochemical $\mathrm{H}_{2}$ production using untreated cellulose and wood sawdust, and HTP cellulose and sawdust at $250^{\circ} \mathrm{C}$ are shown in Fig 4.10 below. We used $3.7 \mathrm{M} \mathrm{H}_{2} \mathrm{SO}_{4}$ as the electrolyte and added $0.08 \mathrm{gm}$ of the sample per milliliter of the electrolyte at each and every potential. Quantities measured as a function of the applied potential $\mathrm{E}^{\mathrm{o}}$ between the cathode and anode are: (i) current; (ii) $\mathrm{H}_{2}$ evolution rate $\mathrm{R}_{\mathrm{H}}$ measured in terms of the area under the $\mathrm{H}_{2}$ peak in $\mathrm{GC}$ and $\mathrm{A}_{\mathrm{H}}$ representing the relative amount of hydrogen produced per watt.hr of energy used. 


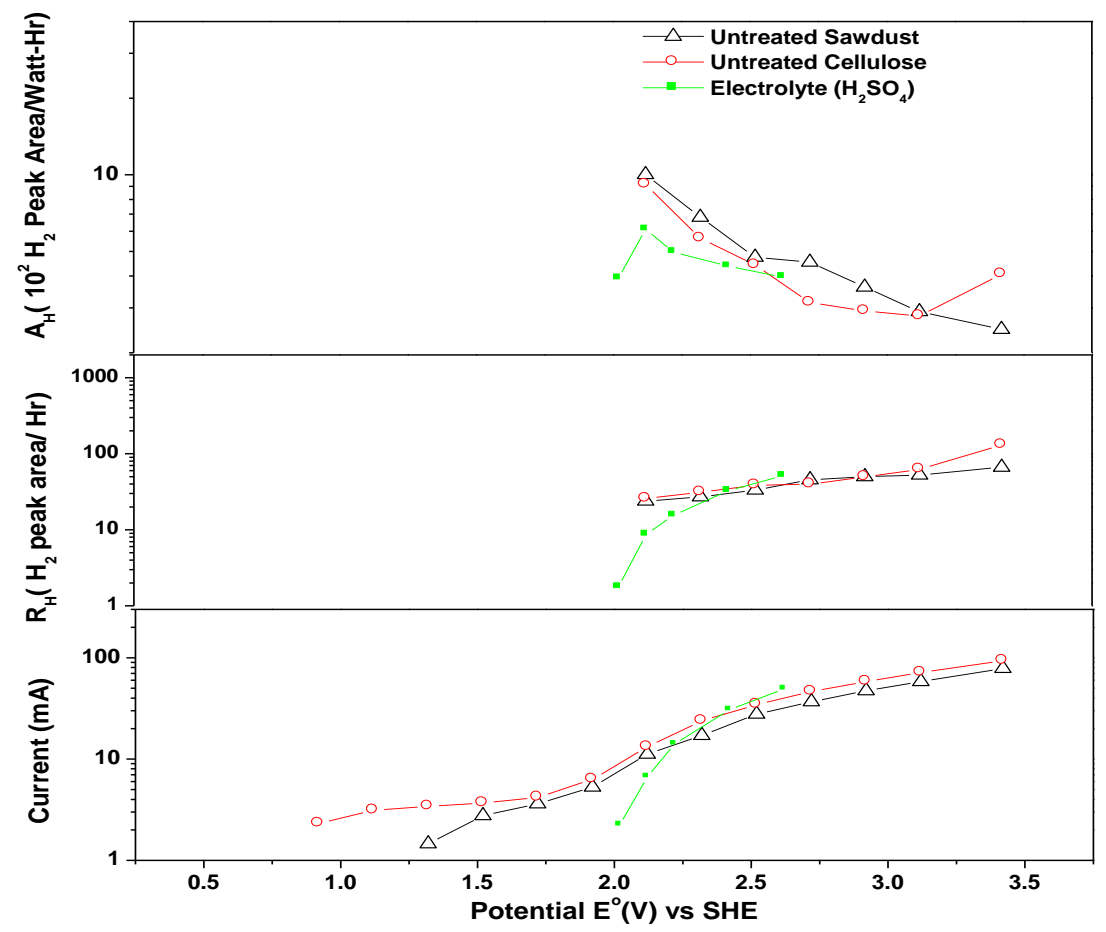

Fig 4.10 Comparison of untreated biomass materials (at $250 \mathrm{C}$ ) and WE

As seen in Fig.4.10, with electrolyte only, no $\mathrm{H}_{2}$ is produced unless $\mathrm{E}^{0}>2 \mathrm{~V}$ is applied to initiate ordinary water electrolysis. Similar results are valid if the untreated cellulose and sawdust are added to the electrolyte showing that untreated biomass samples are essentially inert in this electrochemical process. However, results obtained are significantly different when HTP treated samples are added (Fig.4.11) in that significant current and $\mathrm{H}_{2}$ production gets initiated at applied voltages as low as $\mathrm{E}^{\mathrm{O}} \approx 0.5$ Volts. Furthermore, $\mathrm{R}_{\mathrm{H}}$ and $\mathrm{A}_{\mathrm{H}}$ are practically identical for $\mathrm{HP}$ treated cellulose and activated carbon BP2000, the most efficient carbon tested in our experiments presumably because of its very high surface area of $1500 \mathrm{~m}^{2} / \mathrm{gm}$. 


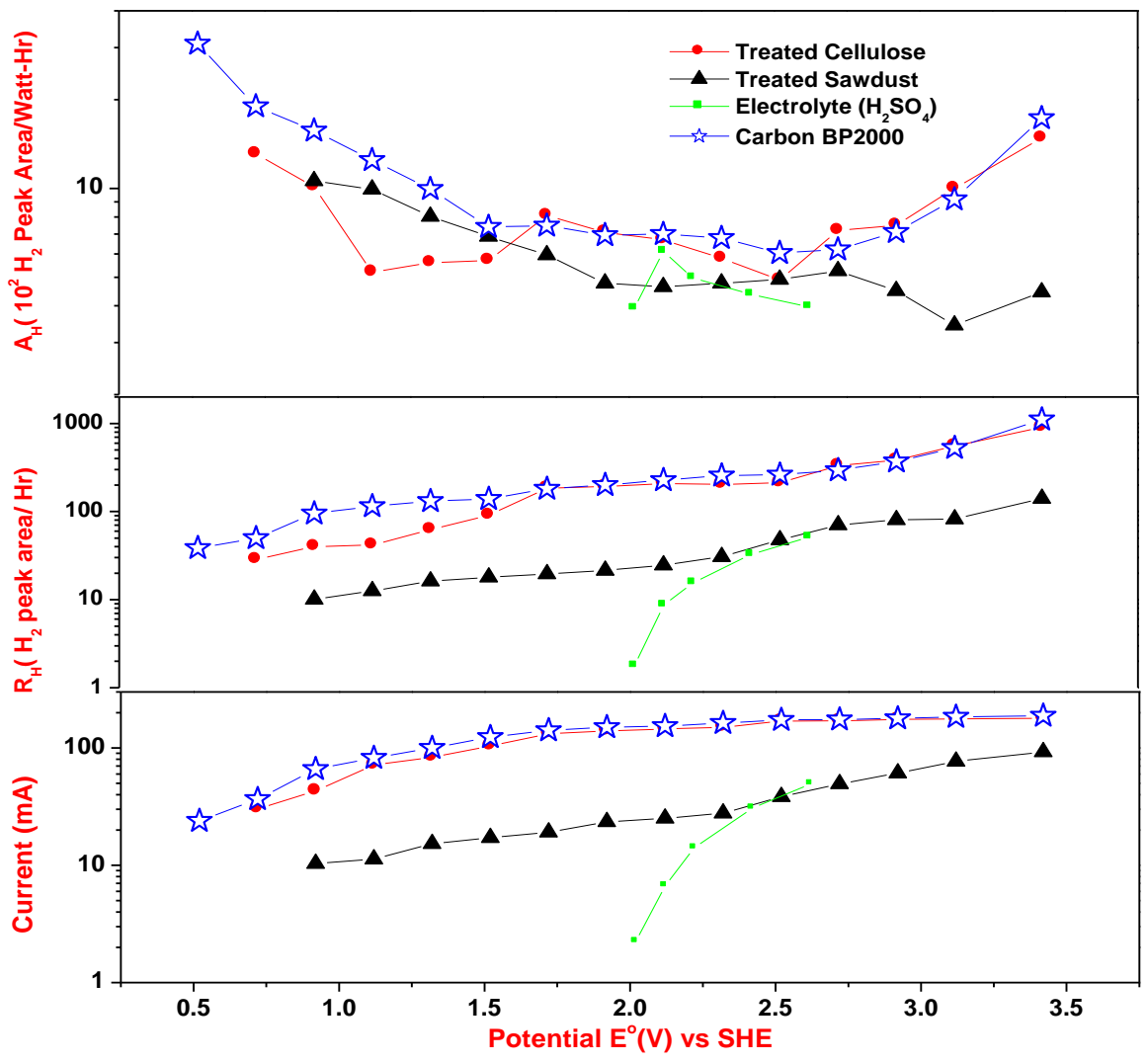

Fig 4.11 Plots of HTP biomass sample and carbon BP2000

\subsubsection{Results of HTP cellulose at $200 \mathrm{C}$ and Carbon BP2000:}

Plots similar to those shown in Fig. 4.11 using HTP cellulose samples treated at $200^{\circ} \mathrm{C}$ for $15 \mathrm{~min}, 30 \mathrm{~min}$ and 1 hour are shown in Fig 4.12 below. 


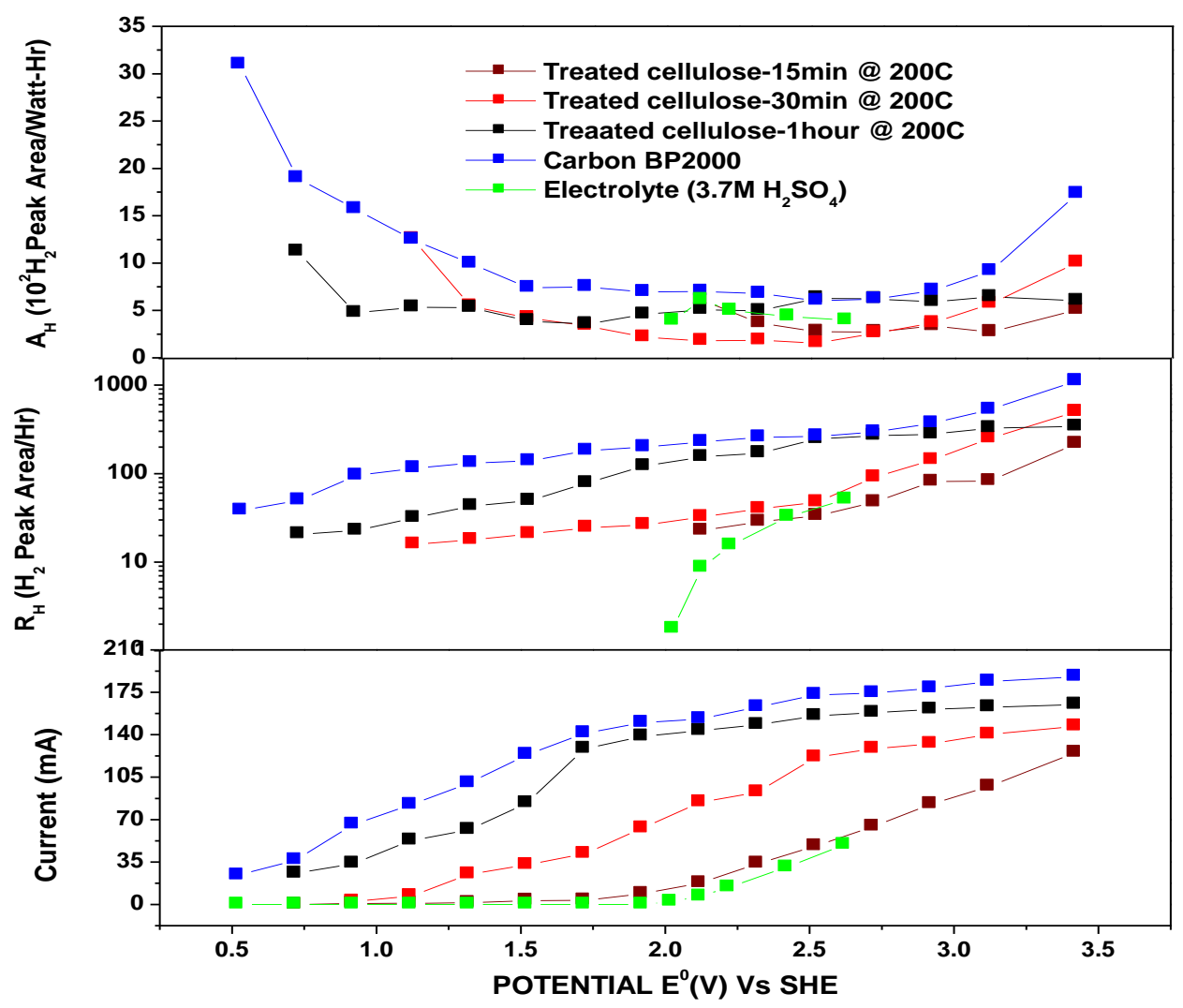

Fig 4.12. Comparison of HTP biomass materials (at $200 \mathrm{C}$ ), carbon BP2000 and WE

These results shown the time for HTP treatment has a huge impact on hydrogen production since the $15 \mathrm{~min}$ treated sample showed less efficiency relatively to $30 \mathrm{~min}$ sample and also it is almost similar to that of water electrolysis and similarly the 1 hour sample proved more efficient compared to the 30 min sample (fig 4.12). Interestingly from the plot we could see that the 1hour sample and the carbon BP2000 results are quite similar. Hence results from this plot made us compare the results obtained with HTP- $200^{\circ} \mathrm{C}$ and HTP- $250^{\circ} \mathrm{C}$ both treated for 1 hour. This is done in the next section.

\subsubsection{Results of HTP cellulose for 1 hour at $200 \mathrm{C}$ vs. $250 \mathrm{C}$ :}

In this section a comparison is made between the HTP cellulose-1 hour sample treated at $200 \mathrm{C}$ and $250 \mathrm{C}$ (Fig 4.13).It is evident that for $\mathrm{E}^{0}<1.7 \mathrm{~V}$, the $250 \mathrm{C}$ sample yields 
somewhat higher magnitude of $\mathrm{R}_{\mathrm{H}}$ and $\mathrm{A}_{\mathrm{H}}$. Therefore, the higher treatment temperature in HTP appears to produce samples with more reactivity for $\mathrm{H}_{2}$ production.

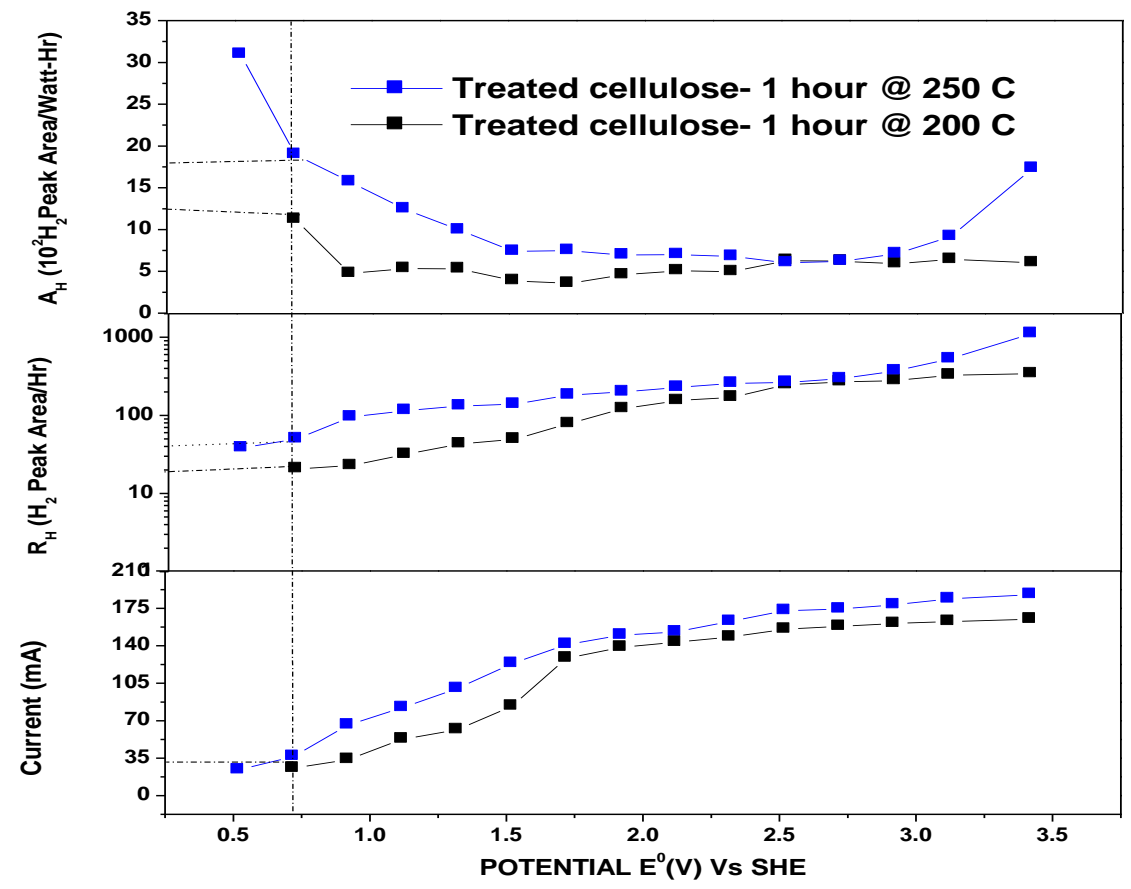

Fig 4.13 Comparison between HTP cellulose for 1 hour at $200 \mathrm{C}$ vs. $250 \mathrm{C}$

As an example consider the results for $\mathrm{E}^{0}=0.72 \mathrm{~V}$, we can see that the current values are nearly the same and the furthermore, the efficiencies i.e. hydrogen evolution rate $R_{H}$ and $A_{H}$ differed by a factor of only 1.2 , thus making not much difference between the samples required for producing hydrogen.

\subsubsection{Efficiency and energy requirements:}

In this section we mainly compare the energy requirements for producing hydrogen of HTP treated biomass samples with ordinary water electrolysis and with carbon BP2000 the most efficient carbon. Fig 4.14 below gives a comparison of HTP biomass materials with ordinary water electrolysis (WE). 


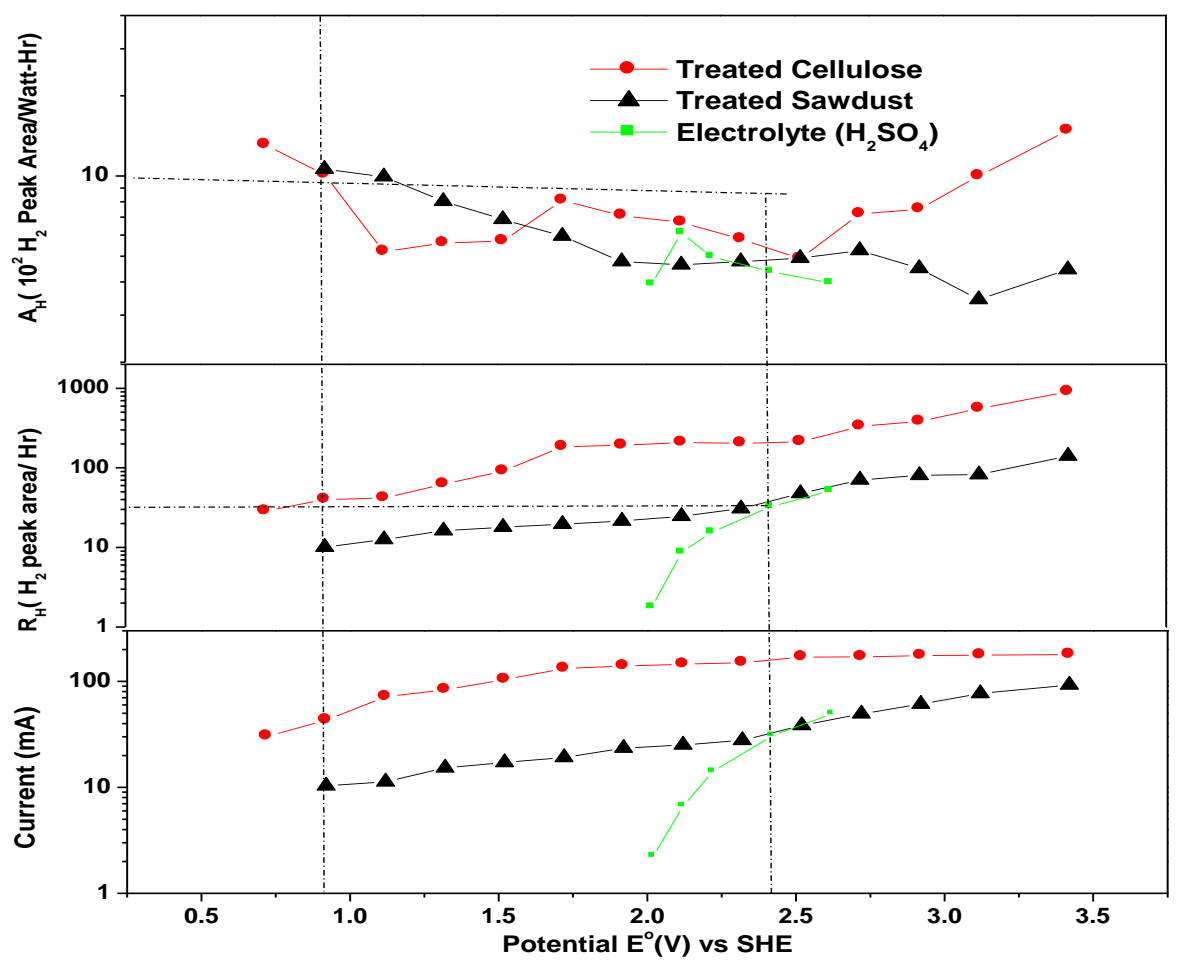

Fig 4.14 Comparison of efficiencies of HTP biomass samples vs. water electrolysis.

From Fig.4.14, the comparison showed that to produce the same rate of hydrogen production, a factor of at-least two improvement in energy efficiency is obtained using biomass materials when working at applied voltage of 1.0 volts as compared to the WE process which requires a higher operating voltage of 2.5 volts for the same rate of hydrogen production and also it is observed that for the HTP sawdust, the magnitudes of current and $R_{H}$ for $E<2 V$ are considerably lower than those observed for HTP cellulose. Hence between HTP cellulose and HTP sawdust, the former one proved to be efficient in producing hydrogen than the later one.

We also compared the results of HTP cellulose sample with carbon BP2000 and the results are discussed and shown in Fig 4.15 below. 


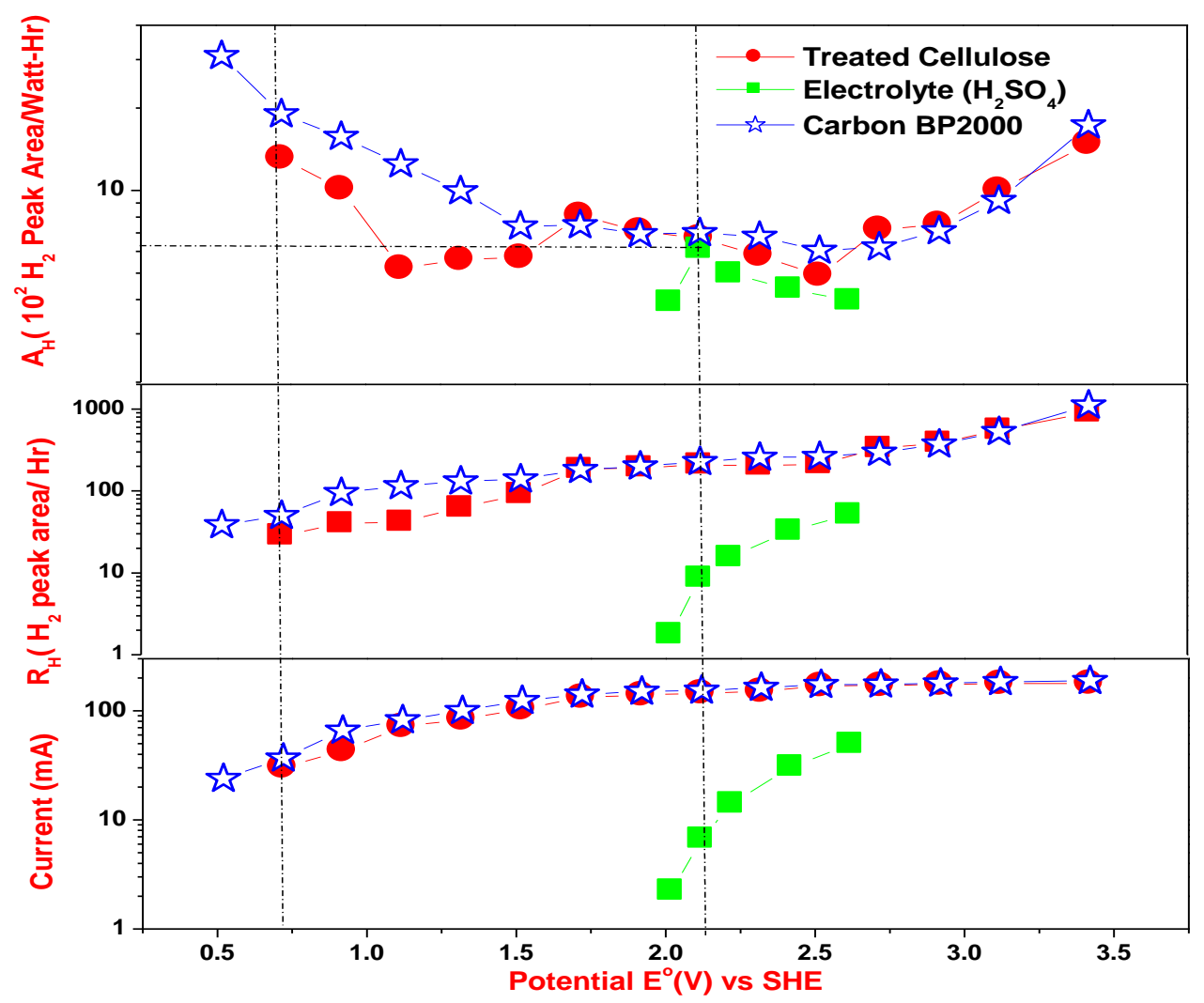

Fig 4.15 Comparison of efficiencies of HTP biomass samples vs. water electrolysis..

As seen in Fig.4.15, with electrolyte only, no $\mathrm{H}_{2}$ is produced unless $\mathrm{E}^{0}>2 \mathrm{~V}$ is applied to initiate ordinary water electrolysis. However, results obtained are significantly different when HTP cellulose is involved in the process as current and $\mathrm{H}_{2}$ production gets initiated at applied voltages as low as $E^{0} \approx 0.5$ Volts. Furthermore, $\mathrm{R}_{\mathrm{H}}$ and $\mathrm{A}_{\mathrm{H}}$ are practically identical for HP treated cellulose and activated carbon BP2000 and when compared to water electrolysis there is a factor of four improvement in efficiency of hydrogen production rate. Hence use of hydrothermally pretreated cellulose in electrochemical experiments shows it to be as effective as high surface area activated carbon BP2000 to produce $\mathrm{H}_{2}$ at energy-efficient voltages beginning at $\mathrm{E}^{\mathrm{0}}=0.5 \mathrm{~V}$ compared to $\mathrm{E}^{\mathrm{o}}>2 \mathrm{~V}$ needed in ordinary water electrolysis. Therefore it is hoped that the 
significant improvements in the hydrogen evolution rate at the energy efficient lower operating voltages reported here will make this process compare favorably with other technologies being considere for producing cost-effective hydrogen. 


\section{CHAPTER 5}

\section{SUMMARY AND CONCLUSIONS}

In this thesis, results on the structural properties of microcrystalline cellulose and wood sawdust are compared with those obtained with these samples after hydrothermal pretreatment (HTP) for different times. It is shown that HTP at $200^{\circ} \mathrm{C}$ for $15 \mathrm{~min}$ and $30 \mathrm{~min}$ is not sufficient to produce products which are sufficiently reactive for electrochemical hydrogen production. However samples obtained after 1 hour- HTP at $200^{\circ} \mathrm{C}$ and $250^{\circ} \mathrm{C}$ show complete breakdown of the cellulose crystallanity. Consequently these samples are found to be very reactive and almost as efficient as high surface area carbon BP2000 for producing hydrogen at energy efficient voltages.

As with carbon BP2000, a factor of about four in energy efficiency compared to ordinary water electrolysis is obtained with these HTP biomass samples. The added advantage of using biomass materials for hydrogen production is that no carbon dioxide could be detected in the process whereas with BP2000 carbon dioxide is produced along with pure hydrogen.

It is noted that in making the above comparisons, the costs involved in producing BP2000 and HTP biomass are not taken into account. Clearly to produce BP2000 and HTP biomass, additional electrical power is used along with other capital and labor costs. For a more realistic economic analysis of CAWE with BP2000 and HTP biomass against water electrolysis, CG and SMR processes, these costs need to be taken into account. However the experiments reported here have shown that HTP-type processes are essential to make biomass reactive for producing hydrogen. Biomass under HTP is shown to breakdown to smaller nearly spherical particles which lack crystallinity in contrast to bulk biomass. 


\section{REFERENCES}

1. P. Kumar, D.M. Barrett, M.J. Delwiche, P Stroeve, "Methods for Pretreatment of Ligno cellulosic Biomass for Efficient Hydrolysis and Bio fuel Production”, ACS, 200948 (8), 3713-3729.

2. M. A. Rosen and D. S. Scott, " Comparative Efficiency Assessments for a range of hydrogen production processes".

3. Coughlin, W.R.; Farooque, M. Electrochemical Gasification of Coal-Simultaneous Production of Hydrogen and Carbon Dioxide by a Single Reaction Involving Coal, Water and Electrons, Ind. Eng. Chem. Process Des. Dev. (1980), 19(2), 211-219.

4. Sukanya Ranganathan M.S. thesis entitled "Carbon Promoted Water Electrolysis to Produce Hydrogen at Room Temperature”, (West Virginia University, 2007).

5. M. S. Seehra, S. Ranganathan and A. Manivannan, "Carbon-assisted water electrolysis: An energy-efficient process to produce pure $\mathrm{H}_{2}$ at room temperature", Appl. Phys. Lett. (2007), 90,044104/1-3. ibid Errantum: (2008), 92, 239902.

6. M.S.Seehra and S.Bollineni, "Nanocarbon boosts energy-efficient hydrogen production in carbon-assisted water electrolysis," International Journal of Hydrogen Energy (2009), Vol. 34, pp 6078-6084.

7. Master's Thesis: Shilpa Bollineni "Hydrogen production via carbon-assisted water electrolysis at room temperature", (West Virginia University, 2008).

8. M. S. Seehra, S. Suri, "On improving the energy efficiency of electro chemical production of hydrogen with promoter $\mathrm{FeSO}_{4}{ }^{\text {“, }}$, ECS presentation, 2010. 
9. Farooque, M.; Coughlin, W.R. Electrochemical, Hydrogen production from coal, water and electrons, Nature (1979), 279,301-303.

10. Farooque, M.; Coughlin, W.R, Electrochemical Gasification of Coal (Investigation of operating conditions and Variables), 1979, vol. 58, p. 705-712.

11. SRI instruments documentation. Multiple Gas Analyzer \#2; (2005)

12. SRI instruments documentation. Thermal Conductivity Detector; (2005) 